\title{
Effects of regional-scale and convective transports on tropospheric ozone chemistry revealed by aircraft observations during the wet season of the AMMA campaign
}

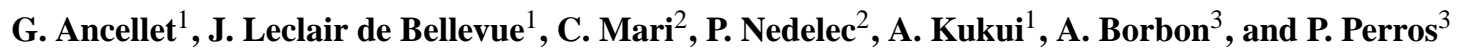 \\ ${ }^{1}$ Service d'Aéronomie, Université Paris 6, Université Versailles-St-Quentin, CNRS, France \\ ${ }^{2}$ Université de Toulouse, CNRS, LA (Laboratoire d'Aérologie), France \\ ${ }^{3}$ Laboratoire Interuniversitaire des Systèmes Atmosphériques, Université Paris 12, CNRS, France
}

Received: 24 June 2008 - Published in Atmos. Chem. Phys. Discuss.: 21 August 2008

Revised: 11 December 2008 - Accepted: 11 December 2008 - Published: 19 January 2009

\begin{abstract}
The African Monsoon Multidisciplinary Analyses (AMMA) fourth airborne campaign was conducted in JulyAugust 2006 to study the chemical composition of the middle and upper troposphere in West Africa with the major objective to better understand the processing of chemical emissions by the West African Monsoon (WAM) and its associated regional-scale and vertical transports. In particular, the french airborne experiment was organized around two goals. The first was to characterize the impact of Mesoscale Convective Systems (MCSs) on the ozone budget in the upper troposphere and the evolution of the chemical composition of these convective plumes as they move westward toward the Atlantic Ocean. The second objective was to discriminate the impact of remote sources of pollution over West Africa, including transport from the middle east, Europe, Asia and from southern hemispheric fires. Observations of $\mathrm{O}_{3}, \mathrm{CO}, \mathrm{NO}_{\mathrm{x}}, \mathrm{H}_{2} \mathrm{O}$ and hydroperoxide above West Africa along repeated meridional transects were coupled with transport analysis based on the FLEXPART lagrangian model. The cross analysis of trace gas concentrations and transport pathways revealed 5 types of air masses: convective uplift of industrial and urban emissions, convective uplift of biogenic emissions, slow advection from Cotonou polluted plumes near the coast, meridional transport of upper tropospheric air from the subtropical barrier region, and meridional transport of Southern Hemisphere (SH) biomass burning emissions. $\mathrm{O}_{3} / \mathrm{CO}$ correlation plots and the correlation plots of
\end{abstract}

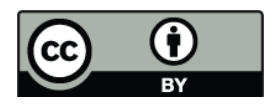

Correspondence to: G. Ancellet (gerard.ancellet@aero.jussieu.fr)
$\mathrm{H}_{2} \mathrm{O}_{2}$ with a $\mathrm{OH}$ proxy revealed not only a control of the trace gas variability by transport processes but also significant photochemical reactivity in the mid- and upper troposphere. The study of four MCSs outflow showed contrasted chemical composition and air mass origins depending on the MCSs lifetime and latitudinal position. Favorables conditions for ozone production were found for MCSs with increased MCS lifetime ( $>1.5$ days), which allowed for more $\mathrm{H}_{2} \mathrm{O}_{2}$ formation, and with trajectories crossing the $10^{\circ} \mathrm{N}$ latitude, which increased $\mathrm{CO}$ transport to the upper troposphere. The upper tropospheric concentrations sampled in the MCS outflow regions showed mixed origins including local vertical convective transport, and uplifting of air from the low troposphere over the middle-east related to the summer Asian low pressure system or from the southern hemispheric fires.

\section{Introduction}

The West African Monsoon (hereafter WAM) is characterized by the migration of zonally banded rainfall from the Guinea coast to the Sahel. This migration is associated with a northward intrusion of a relatively cool, moist air from the Gulf of Guinea into the continent, the so-called monsoon flux (Hall and Peyrillé, 2006). The rainy season over the Sahel corresponds to the northernmost placement of the intertropical convergence zone (ITCZ) - the local signature of the ascending branch of the Hadley cell. The WAM is a complicated system which involves many interactions between the atmosphere, the land surface and the ocean (Zeng et al., 1999; Grodsky and Carton, 2001; Giannini et al., 2003) and

Published by Copernicus Publications on behalf of the European Geosciences Union. 
which is influenced by processes occurring over a range of spatial scales, down to individual rain events on the order of tens of kilometers (Redelsperger et al., 2002; Diongue et al., 2002). In the Sahel region, deep convection occurs in relatively large organized systems known as mesoscale convective systems (MCS) (Chong et al., 1987; Redelsperger et al., 2002; Laing et al., 2008). Based on TRMM measurements, Zipser et al. (2006) identified West Africa as one of the locations on earth with the most very intense storms during the boreal summer season. In the lower troposphere, over West Africa the temperature structure particular to the continent creates a distinct seasonal easterly jet known as the African easterly jet (AEJ) (Thorncroft and Blackburn, 1999; Parker et al., 2005). The West African MCSs intensities and positions are strongly modulated by the AEJ (Mohr and Thorncroft, 2006). In the upper troposphere, a characteristic feature of the WAM is the persistence of a tropical easterly jet (TEJ) which is in evidence over the African continent and the Gulf of Guinea at about $10^{\circ} \mathrm{N}$ and $16 \mathrm{~km}$ altitude (Peyrille et al., 2007). The African Monsoon Multidisciplinary Analyses (AMMA) fourth airborne campaign was conducted in July-August 2006 to study the chemical composition of the middle and upper troposphere in West Africa (Mari and Prospero, 2005; J.L.Redelsperger et al., 2006) and see also Reeves et al. (2009) for a review of the general AMMA achievements and the results of the aircraft measurement intercomparison. One major objective was to provide a better understanding of the processing of chemical emissions by the WAM and its associated regional-scale and vertical transports, briefly described above.

Over Africa, ozone precursors are emitted from soils and vegetation, particularly between $5^{\circ} \mathrm{N}$ and $15^{\circ} \mathrm{N}$ over West Africa (Guenther et al., 1995; Serca et al., 1998; Jaegle et al., 2004, 2005), and from industrialized areas, especially in Nigeria (Olivier et al., 1999; Aghedo et al., 2007). When these emissions are collocated with convective clouds, the emitted gases are transported efficiently in the upper troposphere by convective updrafts depending on their solubility. Since the late 1990s, the subsequent ozone production in the upper troposphere perturbed by deep convection has been inferred from aircraft observations (Thompson et al., 1994) and models (Scala and et al., 1990; Pickering et al., 1991, 1993; Thompson et al., 1996; Pickering et al., 1996). Moreover, the electrical activity associated with deep convection systems at the ITCZ (Christian. et al., 2003) is a major source of $\mathrm{NO}$ in the upper troposphere (Pickering et al., 1996; Martin et al., 2000; DeCaria et al., 2000; Labrador et al., 2005; Huntrieser et al., 2008) and see also Schumann and Huntrieser (2007) for a review. More recently, it was shown that lightning produced $\mathrm{NO}_{\mathrm{x}}$ is of great influence on the ozone distribution in the middle and upper troposphere over Africa (Sauvage et al., 2007c; Saunois et al., 2008) and could be a dominant contributor to the tropical South Atlantic ozone maximum observed during the austral summer (Thompson et al., 2000; Martin et al., 2002; Edwards et al.,
2003; Sauvage et al., 2006, 2007b). An additional source of ozone precursors over Africa is related to biomass burning which leads to large emissions of $\mathrm{CO}$, hydrocarbons and nitrogen oxides. The ozone production above and downwind of the biomass burning regions has been the subject of numerous studies mainly based on aircraft observations during the dry seasons over the Northern Hemisphere (TROPOZ Jonquieres et al., 1998; Jonquieres and Marenco, 1998 - DECAFE - Fontan et al., 1992) or the Southern Hemisphere (TRACE A/SAFARI - Andreae et al., 1996; Fishman et al., 1996) In contrast, only a few studies have been devoted to the possible impact of biomass burning emissions to the ozone budget on the opposite hemisphere. Edwards et al. (2003) have shown the potential for northern hemispheric fires emissions to be uplifted by the convection and transported southwestward above the Gulf of Guinea in the upper troposphere during the boreal winter. Based on the airborne MOZAIC program, Sauvage et al. (2005) have showed the possible impact of southern hemispheric fires on the ozone observations north of the equator, near the guinean coast during the boreal summer. This hypothesis was further confirmed by Mari et al. (2008) with an extensive study of fire tracers during the July-August 2006 period.

The french airborne experiment was organized around two objectives. The first was to characterize the impact of mesoscale convective systems on the ozone budget in the upper troposphere and the evolution of the chemical composition of these convective plumes as they move westward toward the Atlantic Ocean. The second objective was to discriminate the impact of remote sources of pollution over West Africa. This includes transport from the middle east (Li et al., 2001), from Europe (Roca et al., 2005), from Asia (Barret et al., 2008) and from southern hemispheric fires (Sauvage et al., 2005; Mari et al., 2008). In this work, we provide an overview of the french airborne experiment with the French Falcon 20 (F-F20) equipped with gaseous measurements of ozone, $\mathrm{CO}, \mathrm{NO}_{\mathrm{x}}$ and hydroperoxide (i.e. $\mathrm{H}_{2} \mathrm{O}_{2}$ and the sum of the organic peroxides $\mathrm{ROOH}$ ) during the second special operation period (hereafter SOP 2). For the first time, measurements of complementary chemical species were obtained in the upper troposphere over West Africa during the rainy season.

With this paper, we attempt to analyze the aircraft data in the light of the WAM main dynamical features to (1) provide the horizontal variability of trace gas species in the outflow region of MCSs and (2) document the regional scale distribution of trace gas species, mainly across the vegetation gradient over Benin and southwestern Niger and through the transition zone between the continent and the Gulf of Guinea. 

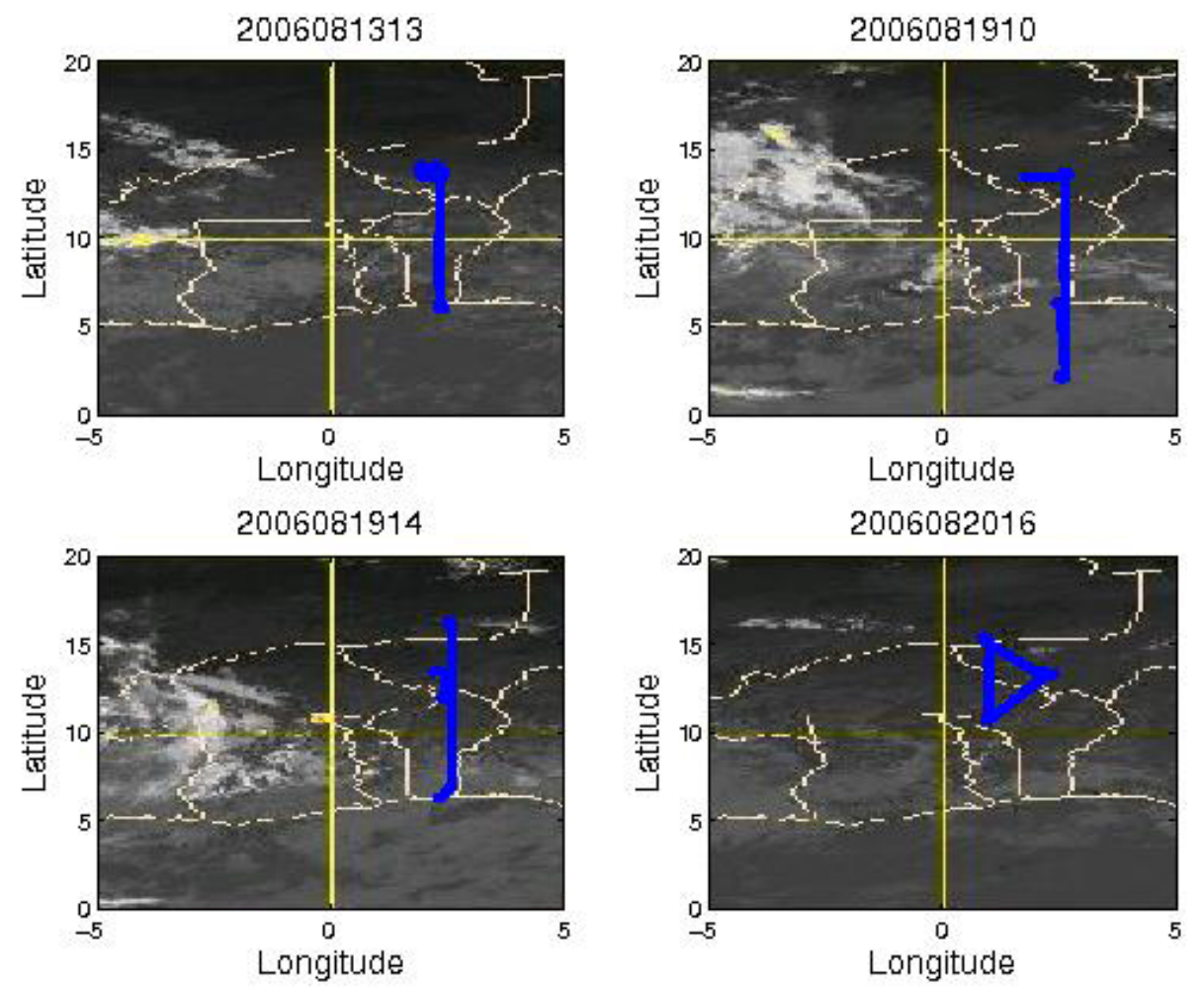

Fig. 1. Aircraft tracks superimposed on MSG/Meteosat pictures at flight mid-time.

\section{Falcon 20 data set}

\subsection{Flight description}

The goals of the F-F20 flights were twofold: (i) measurements of the chemical species in the outflow of various MCSs which have developed during the WAM period, (ii) measurements during the dry spell (i.e. between two convective periods (Cowden et al., 2008)) at a regional scale. The first kind of flights allow a direct study of the chemical composition in the MCS outflows while there are still active. The second kind of flights is important to assess the impact of convective transport at a broader scale and to distinguish this transport pathway from other dynamical processes. The F-F20 aircraft was based in Niamey $\left(13.5^{\circ} \mathrm{N}, 2.1^{\circ} \mathrm{E}\right)$ and performed 8 scientific flights from 11 August to 20 August, plus an intercomparison flight with the British BAe-146 aircraft on 16 August (Table 1).

Four flights were performed in the outflow of active MCSs and the flight patterns are presented in Sect. 4. Four flights were conducted during two dry spells (12 August-13 August) and (19-22 August) to establish a meridional crosssection of the chemical composition in the mid- and upper troposphere over Benin and Niger. These flights are discussed in Sect. 3 and generally include long horizontal tracks at 2 or 3 different altitude levels. The horizontal projection of the flight patterns are shown on the Meteosat Second Generation (MSG) images in Fig. 1. On 20 August, the goal was to fly along the $1^{\circ} \mathrm{E}$ line across the core of the African Easterly Jet (AEJ) located at $15^{\circ} \mathrm{N}$ on this day. For these flights, meteorological dropsondes have been launched every 1 degrees from the uppermost altitude level of the aircraft (i.e. 10 or $12 \mathrm{~km}$ ). The water vapor vertical stratification given by the dropsondes provides a more complete picture of the meridional cross-sections of the chemical tracer than the use of in-situ measurements at 2 or 3 altitude levels. Examples are given in Sect. 3.3 (see Figs. 7a to 7d). The dropsonde wind vertical profiles have been also useful to check the good quality of the ECMWF wind data which have been used in this work for trajectory calculations (Sect. 3.2).

\subsection{Instrument description}

In this paper, concentrations of $\mathrm{O}_{3}, \mathrm{CO}, \mathrm{NO}_{\mathrm{x}}, \mathrm{H}_{2} \mathrm{O}_{2}$, and $\mathrm{ROOH}$ will be used together with the standard meteorological measurements available on the aircraft. Details on the meteorological measurements can be found on the SAFIRE aircraft management team web site (http://www.safire.fr). The relative humidity $(\mathrm{RH})$ measurements are made by the AERODATA capacitive sensor. The chemical measurements are described in the following sections. 
Table 1. List of the F-F20 flights during the AMMA-SOP2.

\begin{tabular}{lll}
\hline Day (UTC) & Location & Features \\
\hline 11 August (12:00-15:30 UTC) & Niger & Long-lived MCS propagating westward over Mali and Burkina Faso \\
13 August (12:15-15:30 UTC) & Niger-Benin & Upper tropospheric meridional transect from Niamey to Cotonou \\
14 August (06:30-09:30 UTC) & Niger & MCS west of Niamey \\
15 August (12:30-15:45 UTC) & Benin & Short-lived MCS north of Benin \\
16 August (09:00-12:00 UTC) & Niger & Intercomparison flight \\
17 August (09:00-12:00 UTC) & Niger & MCS north-west of Niamey \\
19 August (09:00-12:00 UTC) & Niger-Benin & Meridional transect from Niamey to Cotonou, plus sortie over the Gulf of Guinea \\
19 August (13:30-16:00 UTC) & Niger-Benin & Meridional transect from Cotonou to Niamey, plus northward exploration over Mali \\
20 August (14:00-17:30 UTC) & Niger & AEJ exploration west of Niamey \\
\hline
\end{tabular}

\subsection{1 $\mathrm{O}_{3}$ and $\mathrm{CO}$ measurements}

The $\mathrm{O}_{3}$ and $\mathrm{CO}$ instrument has been manufactured by Laboratoire d'Aérologie and DT-INSU (CNRS Technical Division). It is a compact instrument developed using the experience gained from the MOZAIC measurement program on commercial Airbus A340 aircraft. The $\mathrm{O}_{3}$ measurement principle and cells are coming from a commercial fast response ozone analyzer (Model 49C TEI Thermo Environment Instruments, USA). The instrument is based on classic UV absorption in two parallel cells (zero, sample), with a precision of $2 \mathrm{ppb}, 2 \%$ for an integration time of $4 \mathrm{~s}$. It is compensated for aircraft pressure and temperature variations. For $\mathrm{O}_{3}$, the instrument is calibrated against a NIST referenced $\mathrm{O}_{3}$ calibrator Model49PS, at levels 0, 250, 500 and $750 \mathrm{ppb}$. No difference $(<1 \%)$ has been observed during the calibrations before and after the campaign

The $\mathrm{CO}$ analyzer is based on a commercial infrared absorption correlation gas analyzer (Model 48C, TEI Thermo Environment Instruments, USA). Its accuracy has been improved by the addition of periodical $(20 \mathrm{~min})$ accurate zero measurements, new IR detector with better cooling and temperature regulation, pressure increase and regulation in the absorption cell, increased flow rate to $41 / \mathrm{min}$, water vapor trap and ozone filter (Nedelec et al., 2003). The precision achieved for a 30-s integration time (corresponding to the response time of the instrument) is $5 \mathrm{ppb}$ or $5 \% \mathrm{CO}$, with a lower detection limit of $10 \mathrm{ppb}$.

For $\mathrm{CO}$, the instrument has been calibrated before and after the campaign, with no significant difference $(<2 \%)$. We used a $\mathrm{CO}$ in $\mathrm{N}_{2}$ bottle manufactured by Air Liquide, reference OTO-SL24, $478.8 \mathrm{ppm}$, NIST referenced $\pm 1 \%$. This bottle was prepared on 14 November 2005, with validity up to 13 November 2008. This bottle has been again measured in 2007 by CNRS and Air Liquide and the concentration was found unchanged. On 23 May 2007, this bottle has been inter compared by DLR with 2 NOAA standards and was found to have a concentration $7.2 \%$ lower. No clear explanation is available for these standards differences, all normally comparable to NIST references. CO concentrations given in this paper are not corrected for this difference and must be divided by 1.072 for comparison with the other aircraft.

\subsubsection{Peroxide measurements}

Peroxide has been measured by well-established enzyme catalyzed fluorescence technique using modified AEROLASER AL2002 $\mathrm{H}_{2} \mathrm{O}_{2}$ analyser. This method has been widely used for the airborne $\mathrm{H}_{2} \mathrm{O}_{2}$ measurements and past studies have shown that this instrument is sufficiently accurate and sensitive for the ambient $\mathrm{H}_{2} \mathrm{O}_{2}$ detection, although not suitable for the accurate quantitative analysis of the organic peroxides (Reeves and Penkett, 2003; Lee et al., 2000). The latter is still useful for a qualitative analysis of the role of organic peroxides.

In this instrument, ambient air was continuously drawn by PTFE membrane compressor (KNF N860) through the rear facing inlet and a 2-m Teflon (PFA) tubing into cylindrical $500 \mathrm{~cm}^{-3}$ Teflon (PFA) manifold with flow rate of about $10 \mathrm{slm}$ at altitude of $11 \mathrm{~km}$ ( $p=200$ torr). The manifold was maintained at the pressure and temperature of the aircraft cabin and served as a sampling volume for several instruments, including the $\mathrm{H}_{2} \mathrm{O}_{2}$ analyzer.

The $\mathrm{H}_{2} \mathrm{O}_{2}$ measurements are based on the aqueous phase enzyme catalyzed reaction of the peroxides with parahydroxy phenol acetic acid producing fluorescent dimer (Lazrus et al., 1988). To distinguish between $\mathrm{H}_{2} \mathrm{O}_{2}$ and organic peroxides ( $\mathrm{ROOH})$, both being catalyzed by the peroxidise enzyme, the air sampled from the PFA cylinder at the flow rate of $2 \mathrm{slm}$ is equally divided between two channels. In each channel the gaseous peroxides are trapped in the liquid solution using 10 turns glass stripped coils. In one of the channels the $\mathrm{H}_{2} \mathrm{O}_{2}$ is partially destroyed by addition of catalase. The concentration of $\mathrm{H}_{2} \mathrm{O}_{2}$ in air is derived from the difference of the fluorescence signals from the two channels with accounting for the destruction efficiency of the catalase, about $95 \%$ for all measurements as determined by calibration. As the stripping efficiency of the ROOH is different from that of the $\mathrm{H}_{2} \mathrm{O}_{2}$, the measurements of the organic peroxides mixtures of unknown composition is uncertain. The 
data presented here as $\mathrm{ROOH}$ were derived by taking for all the organic peroxides the same stripping efficiency of $60 \%$ as for the methylhydroperoxide (Lazrus et al., 1988). For measurements in remote area or in the free troposphere, the latter is the main organic hydroperoxide and the uncertainty on the $\mathrm{ROOH}$ concentration is less important.

The calibration of the instrument has been performed before or after each flight (and occasionally during the flight) using aqueous phase $\mathrm{H}_{2} \mathrm{O}_{2}$ standard solutions. The standards with mixing ratios ( 2 to 6$) \times 10^{-7} \mathrm{M}$ were freshly prepared by serial dilution of $10^{-2} \mathrm{M}$ stock solution. The concentration of the stock solution has been periodically verified by titration with potassium permanganate.

The base line has been measured about once per hour during the flight by passing the sampled air through the trap containing $\mathrm{H}_{2} \mathrm{O}_{2}$ scrubber. With freshly prepared solutions the zero signal was about $0.1 \mathrm{~V}$ at $5 \mathrm{~V}$ full scale adjusted to correspond to about $10 \mathrm{ppb}$ maximum gaseous $\mathrm{H}_{2} \mathrm{O}_{2}$ concentration. During the same flight the variation of the zero signal was always less than $10 \%$ corresponding to $\mathrm{H}_{2} \mathrm{O}_{2}$ concentration of about $20 \mathrm{ppt}$.

Based on the stability of the blank the detection limit for the $\mathrm{H}_{2} \mathrm{O}_{2}$ was estimated to be $50 \mathrm{ppt}$. The estimated accuracy of $\mathrm{H}_{2} \mathrm{O}_{2}$ measurements is $20 \%$, including the uncertainties in concentration of aqueous $\mathrm{H}_{2} \mathrm{O}_{2}$ standards, blanks, gas and solution flow rates, losses of the $\mathrm{H}_{2} \mathrm{O}_{2}$ in sampling lines and temperature and pressure variations inside the aircraft.

\subsection{3 $\quad \mathrm{NO}_{\mathrm{x}}$ measurements}

The $\mathrm{NO}_{\mathrm{x}}$ measurements were performed by the LISA laboratory instrument using two high sensitivity chemiluminescent analyzers (Eco Physics CLD 780 TR). The instrument has been flown during previous field measurements (Marion et al., 2001) and it has been modified for operation on the F-F20.

$\mathrm{NO}$ is directly measured by the first analyzer and $\mathrm{NO}_{2}$ is measured by a second instrument after conversion to NO. In order to improve the detection limit for $\mathrm{NO}_{2}$ we use a special designed photolytical converter (Eco Physics PLC-762) where $\mathrm{NO}_{2}$ is converted to $\mathrm{NO}$ with a high conversion efficiency by the use of a long path photolytic cell $(0.91 \mathrm{~m})$ and a $1-\mathrm{kW}$ UV xenon lamp. The Pyrex chamber is cooled to $22^{\circ} \mathrm{C}$ below the ambient temperature by the use of Peltier elements in order to prevent a possible thermal decomposition of PAN.

The measurement cycles are divided into two different steps. The first step corresponds to the zero determination by introducing excess ozone into a pre-reaction chamber. The second step is the direct measurement by adding ozone into the main chamber. The duration of both steps was $12 \mathrm{~s}$ during the campaign, allowing a sample time step of $30 \mathrm{~s}$. For this integration time the detection limit for each $\mathrm{NO}$ analyzer is $50 \mathrm{ppt}$ and the precision of the measurements is $0.5 \%$. These values are calculated using a statistical treatment following a French norm (AFNOR NF X20-300).
The $\mathrm{NO}$ and $\mathrm{NO}_{2}$ instruments are connected to an airintake stainless steel with a backward-facing inlet. This design allows us to assume that the air sample corresponds solely to the gas phase and that there is no intake of clouds and aerosols. PFA Teflon is used for all the sampling lines, connectors and valves. The sampling lines are flushed with purified air at ground level in order to prevent contamination, and a subsequent memory effect, of the analytical system. To maintain efficient operation of the analyzers at all altitudes it is necessary to fix the sample flow of each analyzer. Instead of flow rates control with mass flow controllers which can induce a possible modification of the air sample by their metallic surfaces, the flow is controlled by the use of a fixed $200 \mathrm{hPa}$ pressure applied to a critical orifice. The chosen pressure does not allow operation above $12 \mathrm{~km}$ a.s.l. For each analyzer the pressure is controlled with a loop control process using a Teflon needle valve (Whitey) driven by a motor (MKS) and a PID pressure controller (MKS Model 252). Pressure is monitored with a MKS Baratron (Type 122A).

For each flight, calibrations are performed simultaneously for the two chemiluminescent analyzers before take off and after landing. All procedures are computer driven to ensure the best accuracy. A standard $8.47 \mathrm{ppmv}$ NO (Alphagaz) (8 $\mathrm{ml} / \mathrm{min} \mathrm{STP}$ ) diluted in a 10 liter/min STP $\mathrm{N}_{2} / \mathrm{O}_{2}$ synthetic air (Air Liquide) stream allows us to generate $6.77 \mathrm{ppbv} \mathrm{NO}$ calibration gas. This gas is then supplied simultaneously to the two analyzers. Since the chemiluminescent analyzers have shown a temperature dependent sensitivity, the calibration coefficients, which were determined at a given temperature, have been corrected at each sampling time by linear interpolation.

\section{Analysis of the regional vertical cross-section}

\section{1 $\mathrm{O}_{3}, \mathrm{CO}$, and $\mathrm{NO}_{\mathrm{x}}$ variability and air mass attribution}

Measured concentrations along the vertical cross-sections at the same longitude $\left(2^{\circ} \mathrm{E}\right.$ on 13 August 2006 and 19 August 2006 and $1^{\circ} \mathrm{E}$ on 20 August 2006) are shown in Figs. 2a to $2 \mathrm{~d}$. As expected a significant variability of the chemical species concentrations is observed as a function of altitude and latitude. Hereafter we will discuss the large increase or decrease of the concentrations compared to their mean value. The aim is also to propose an air mass identification using relationship between the measured concentrations which are based on possible transport processes driving their variability. This is the first step needed to assess the meaning of the aircraft data.

\subsubsection{Ozone and CO}

First, the vertical distributions show large area with high $\mathrm{CO}$ values $(>140 \mathrm{ppb})$ and low $\mathrm{O}_{3}$ concentrations $(<50 \mathrm{ppb})$ at altitudes above or near $10 \mathrm{~km}$ especially at the beginning of 

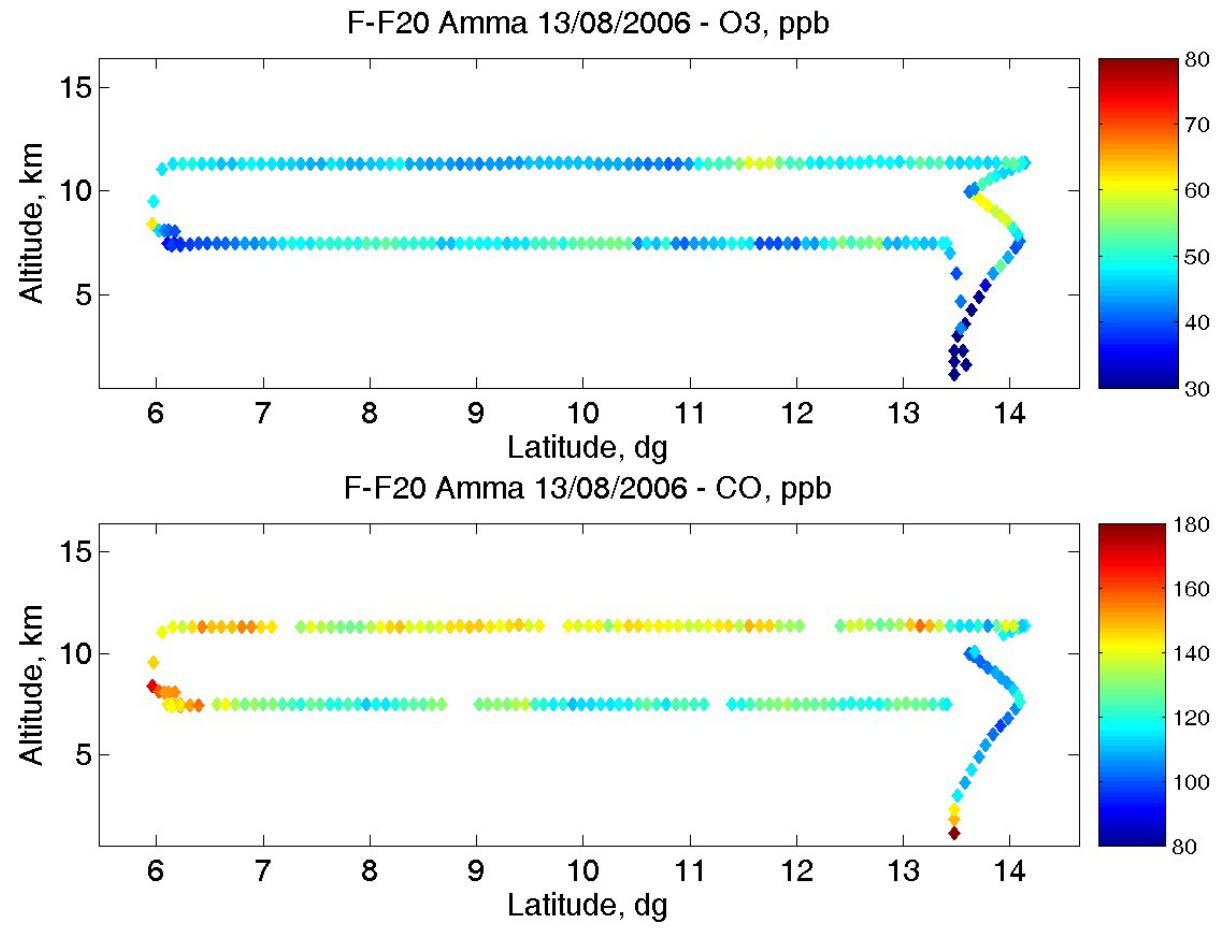

Fig. 2a. Altitude vs. latitude distribution of $\mathrm{O}_{3}$ and $\mathrm{CO}$ mixing ratio in ppb along the 13 August $\mathrm{LRT}$ flight (no $\mathrm{NO}_{\mathrm{x}}$ measurements).

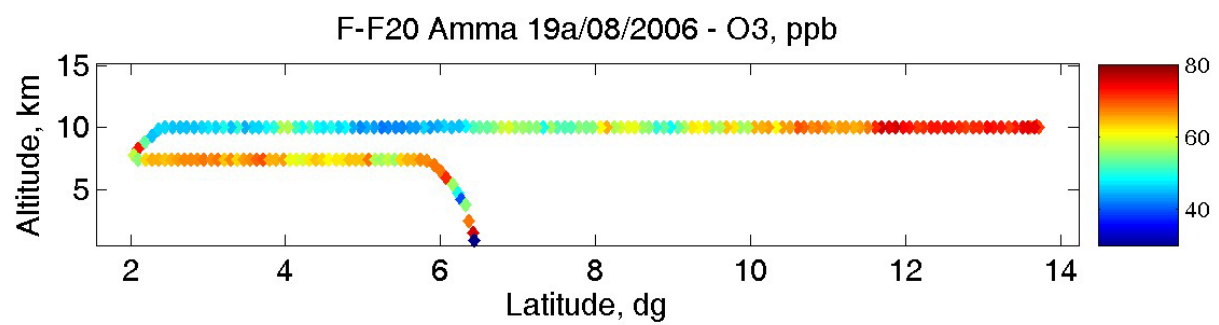

F-F20 Amma 19a/08/2006 - CO, ppb

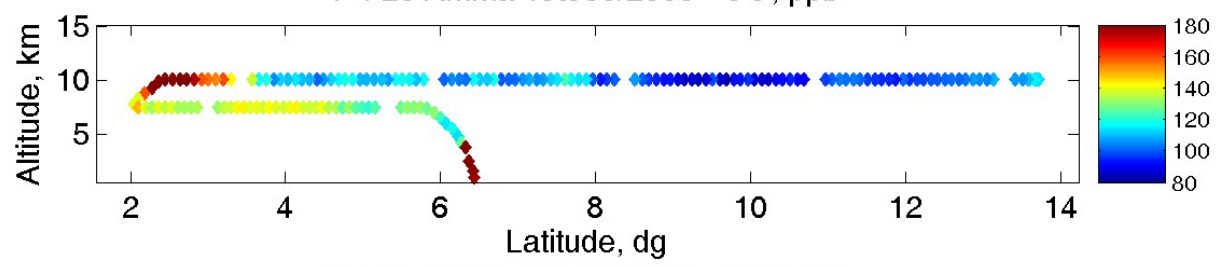

F-F20 Amma 19a/08/2006 - NOx, ppt

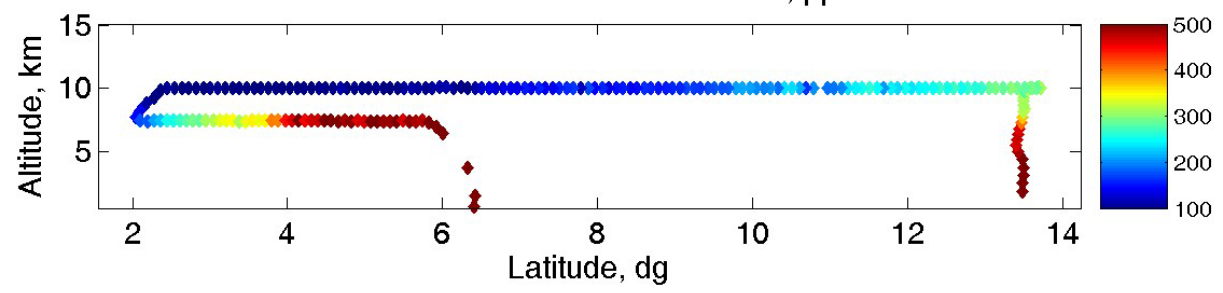

Fig. 2b. Altitude vs. latitude distribution of $\mathrm{O}_{3}, \mathrm{CO}$, and $\mathrm{NO}_{\mathrm{x}}$ mixing ratio in ppb along the 19 August $\mathrm{LRT}$ flight (a.m.). 

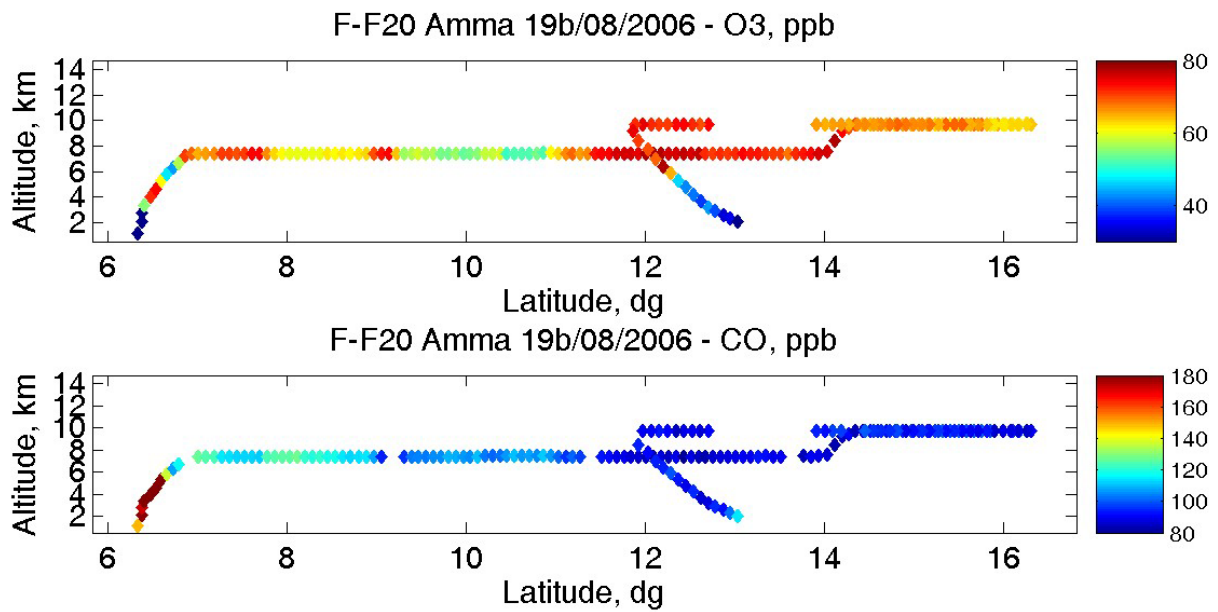

F-F20 Amma 19b/08/2006 - NOx, ppt

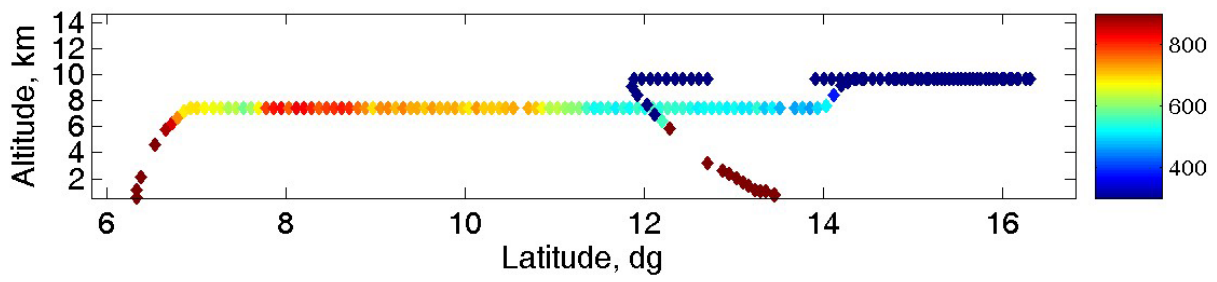

Fig. 2c. Altitude vs. latitude distribution of $\mathrm{O}_{3}, \mathrm{CO}$, and $\mathrm{NO}_{\mathrm{x}}$ mixing ratio in ppb along the 19 August LRT flight (p.m.).

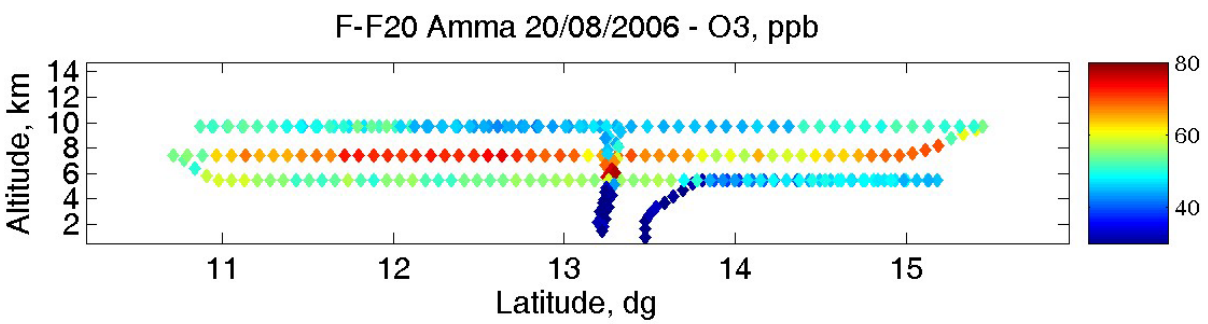

F-F20 Amma 20/08/2006 - CO, ppb

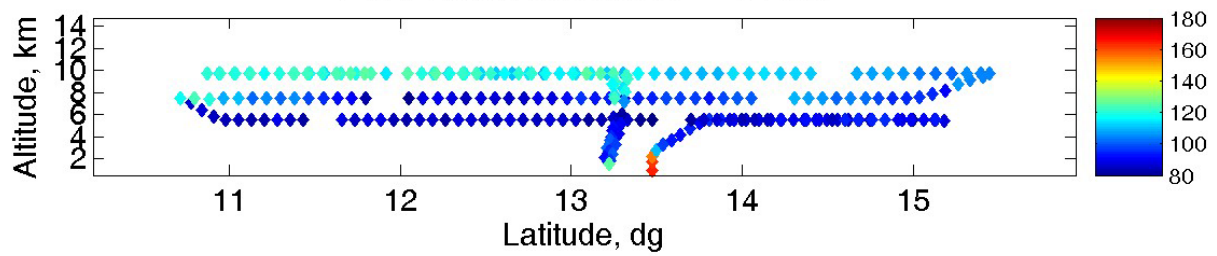

F-F20 Amma 20/08/2006 - NOx, ppt

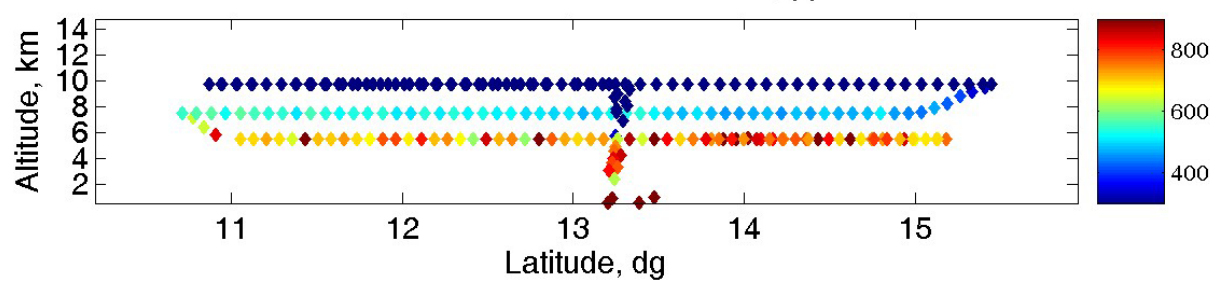

Fig. 2d. Altitude vs. latitude distribution of $\mathrm{O}_{3}, \mathrm{CO}$, and $\mathrm{NO}_{\mathrm{x}}$ mixing ratio in ppb along the 20 August LRT flight. 


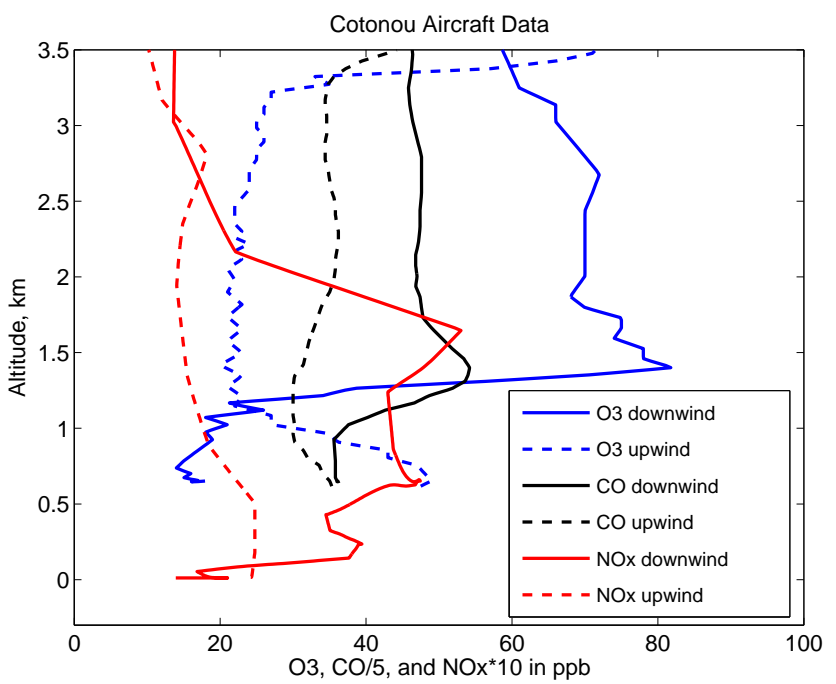

Fig. 3. Profiles of $\mathrm{O}_{3}, \mathrm{CO}$ and $\mathrm{NO}_{\mathrm{x}}$ in ppb during landing (19 August a.m. - downwind) and take-off (19 August p.m. - upwind) from Cotonou (Benin).

the flight campaign (13 August). The same is true for exactly the opposite case, i.e. low $\mathrm{CO}(<110 \mathrm{ppb})$ and high $\mathrm{O}_{3}$ concentrations ( $>70 \mathrm{ppb}$ ) mainly in the Northern part of the measurement domain (19 August, 20 August). Only a few observations correspond to air masses where $\mathrm{CO}$ and $\mathrm{O}_{3}$ are correlated positively.

In the altitude range $0-4 \mathrm{~km}$, data are obtained mainly from take off and landing of the F-F20 in Niamey and Cotonou and significant differences have been observed between the vertical profiles of $\mathrm{CO}$ and $\mathrm{O}_{3}$ at these two places. Ozone concentrations higher than $60 \mathrm{ppb}$ are only observed near Cotonou $\left(6.4^{\circ} \mathrm{N}, 2.5^{\circ} \mathrm{E}\right)$ and large $\mathrm{CO}$ concentrations are observed at both latitudes but below $2 \mathrm{~km}$ above Niamey and up to $4 \mathrm{~km}$ near Cotonou. The profiles measured near Cotonou on 19 August 2006 are shown in Fig. 3. Three layers can be identified: the planetary boundary layer up to $1 \mathrm{~km}$ with low $\mathrm{O}_{3}$, a transition layer with the free troposphere up to $2.5 \mathrm{~km}$ and the lowermost free troposphere between 2.5 and $3.5 \mathrm{~km}$. Only the transition layer and the lowermost free troposphere show the elevated $\mathrm{O}_{3}$ and $\mathrm{CO}$ values.

Following Andreae et al. (1994), one can study the chemical history of sampled air masses using the correlation of ozone excess versus $\mathrm{CO}$ excess, $\Delta\left[\mathrm{O}_{3}\right]$ versus $\Delta[\mathrm{CO}]$. Ozone excess is defined here as the ozone concentration corrected by a reference ozone vertical profile which increases linearly with altitude from $20 \mathrm{ppb}$ at $3 \mathrm{~km}$ to $50 \mathrm{ppb}$ at $12 \mathrm{~km}$. The $\mathrm{CO}$ excess is defined as the difference of the measured $\mathrm{CO}$ concentrations with a threshold $\mathrm{CO}$ value of $100 \mathrm{ppb}$ which corresponds to non polluted tropospheric conditions according to Sauvage et al. (2007a). In Fig. 4, the correlation plot of $\Delta\left[\mathrm{O}_{3}\right]$ versus $\Delta[\mathrm{CO}]$ shows a negative correlation which suggests a combined influence, on one hand of convective

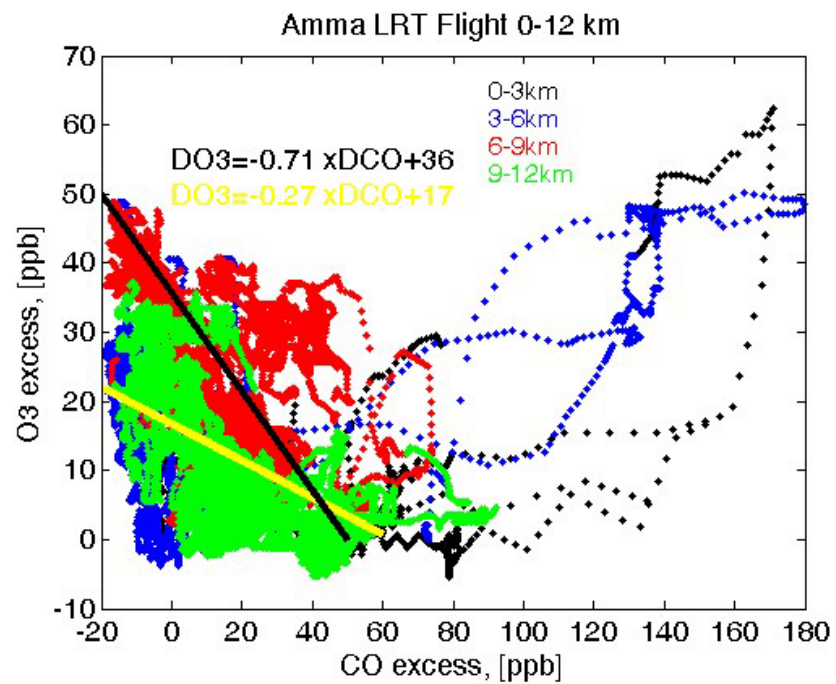

Fig. 4. Scatter plot of $\mathrm{O}_{3}$ excess vs. $\mathrm{CO}$ excess in $\mathrm{ppb}$ as measured by the F-F20 during the four LRT flights.

uplifting of low level air masses with high $\mathrm{CO}$ and low ozone (i.e. where $\mathrm{NO}_{\mathrm{y}}$ was eliminated by wet scavenging in the monsoon layer or where $\mathrm{O}_{3}$ was titrated in very polluted areas: oil industry, urban cities like Lagos or Cotonou) and on the other hand of dry intrusions from the upper troposphere with high ozone and low CO. Two different lines with high and low gradient have been drawn in Fig. 4 and they correspond to the two main groups identified in this figure. The first one has a gradient of -0.7 close to the value of -1 corresponding to stratospheric intrusion as shown by the analysis of the MOZAIC aircraft data (Brioude et al., 2007), while the higher one $(-0.3)$ can be related to air masses with ozone chemical loss as measured at mid-latitudes in polluted air masses during the winter time (Parrish et al., 1998). Although part of this correlation could be related also to mixing of stratospheric intrusions with polluted air masses, i.e. with large $\mathrm{CO}$ values and $\mathrm{O}_{3}$, this is not very likely at tropical latitudes where the stratospheric intrusions remain at high altitudes and do not cap urban pollution plumes as they do at mid-latitudes (Cho et al., 2001). The polluted air mass corresponds to the data collected during landing and take off from Cotonou on 19 August and the corresponding data appears on the plot as the region with positive gradient between $\Delta\left[\mathrm{O}_{3}\right]$ and $\Delta[\mathrm{CO}]$ of the order of 0.3 .

\subsection{2 $\quad \mathrm{NO}_{\mathrm{x}}$ and relative humidity}

The $\mathrm{NO}_{\mathrm{x}}$ concentrations are only available on $19 \mathrm{Au}-$ gust 2006 and 20 August 2006. Mixing rations ranges between $100 \mathrm{ppt}$ and $400 \mathrm{ppt}$ above $7 \mathrm{~km}$ and from 600 $4000 \mathrm{ppt}$ below $4 \mathrm{~km}$. The ratio $\mathrm{NO}_{2}$ over $\mathrm{NO}$ is generally higher than expected (not shown) suggesting either very reduced $\mathrm{NO}_{2}$ photodissociation coefficient or high $\mathrm{RO}_{2}$ radical 
concentrations shifting the $\mathrm{NO}_{\mathrm{x}}$ partitionning towards large $\mathrm{NO}_{2}$, especially for low $\left[\mathrm{O}_{3}\right]$ concentrations. A detailed and careful analysis of the $\mathrm{NO}_{\mathrm{x}}$ partitioning relevant for a quantitative $\mathrm{O}_{3}$ production assessment is not within the scope of this paper. In this work, only the total $\mathrm{NO}_{\mathrm{x}}$ concentration will be used to distinguish air masses which have been exposed to high or low $\mathrm{NO}_{\mathrm{x}}$ emissions. The high $\mathrm{NO}_{\mathrm{x}}$ concentrations above $7 \mathrm{~km}$ are often related to a relative increase of RH suggesting influence of convective activity (vertical transport of soil emissions or NO production by lightning). Below $4 \mathrm{~km}$, contrary to the $\mathrm{CO}$ vertical distribution the highest $\mathrm{NO}_{\mathrm{x}}$ concentrations near Cotonou iare only found below $2.5 \mathrm{~km}$. Therefore transport processes controlling the composition of the transition layer $(1-2.5 \mathrm{~km})$ and the lowermost free troposphere $(2.5-4 \mathrm{~km})$ are different although homogeneity would have been inferred from the $\mathrm{O}_{3}$ and $\mathrm{CO}$ vertical profiles.

The in-situ RH measurements made by the Falcon have also been used since it gives information on vertical transport, because high RH can be often related to recent uplift from the Planetary Boundary Layer (PBL) and low RH to subsidence from the upper troposphere. The aircraft RH data have been compared to the dropsonde measurements (see Figs. 7a to 7d in Sect. 3.3) and are in good agreement.

\subsubsection{Air mass clustering using chemical tracer observa- tions}

Looking at positive or negative anomalies of the $\mathrm{O}_{3} / \mathrm{CO} / \mathrm{NO}_{\mathrm{x}} / \mathrm{H}_{2} \mathrm{O}$ concentrations along the F-F20 tracks, one can identify five different types of air masses:

- Type I where the main characteristics are low $\mathrm{O}_{3}(<50 \mathrm{ppb})$ and high $\mathrm{CO}$ concentrations ( $\left.\gtrsim 150 \mathrm{ppb}\right)$ i.e. possible export of polluted air mass with $\mathrm{O}_{3}$ chemical loss in the monsoon layer

- Type II where the main characteristics are opposite to the previous one: low $\mathrm{CO}(\lesssim 100 \mathrm{ppb})$ and high $\mathrm{O}_{3}$ concentrations $(>70 \mathrm{ppb})$ together with low relative humidity $(\mathrm{RH}<30 \%)$. This could be related to dry intrusions of ozone rich air masses from the tropopause region into the free troposphere.

- Type III where the main characteristics are very high $\mathrm{CO}(\gtrsim 200 \mathrm{ppb})$ and high $\mathrm{NO}_{\mathrm{x}}$ concentrations $(\gtrsim 1 \mathrm{ppb})$ at low altitudes $(<3 \mathrm{~km})$, while significant $\mathrm{O}_{3}$ production is also observed with concentrations higher than $60 \mathrm{ppb}$. These air masses were encountered near Cotonou.

- Type IV where the main characteristics are similar to the previous ones but with lower concentrations: $[\mathrm{CO}]>130 \mathrm{ppb},\left[\mathrm{O}_{3}\right] \approx 70 \mathrm{ppb}$ and $\left[\mathrm{NO}_{\mathrm{x}}\right] \approx 300 \mathrm{ppt}$. This group has been chosen to to correspond to what is expected for an air mass with ozone production related to biomass burning emissions or aged anthropogenic sources (high $\mathrm{CO}$ )

- Type V where the main characteristics are $100 \mathrm{ppb}<[\mathrm{CO}]<130 \mathrm{ppb} \quad$ with $\quad\left[\mathrm{O}_{3}\right] \approx 60 \mathrm{ppb}$, $\left[\mathrm{NO}_{\mathrm{x}}\right]>500 \mathrm{ppt}$ and $\mathrm{RH}>30 \%$. This group has been chosen to consider an air mass with ozone production but not clearly related to biomass burning or aged anthropogenic emissions (no elevated $\mathrm{CO}$ concentrations)

Table 2 summarizes the position of the different air mass types for the 4 flights discussed in this section. Regarding the type III air mass observed near Cotonou on 19 August (Fig. 3), ozone precursor emissions, related to this large city of 1 million inhabitants with frequent air pollution problems, may explain the layer observed between 1 and $3.5 \mathrm{~km}$ during the descent to Cotonou. Indeed the comparison between the vertical profiles recorded during landing at 12:00 and takeoff $1.5 \mathrm{~h}$ later allows the comparison between an air mass $15 \mathrm{~km}$ upwind (during take-off) and $10 \mathrm{~km}$ downwind (during landing) of the Cotonou emissions. It shows a $\mathrm{CO}$ and $\mathrm{NO}_{\mathrm{x}}$ difference of respectively $70 \mathrm{pbb}$ and and $3.5 \mathrm{ppb}$, while the $\mathrm{O}_{3}$ concentration is near 25-ppb in the upwind layer and reaches $70 \mathrm{ppb}$ in the layer downwind of Cotonou. Considering the downwind $\mathrm{CO}$ and $\mathrm{NO}_{\mathrm{x}}$ concentrations (respectively $240 \mathrm{ppb}$ and $5 \mathrm{ppb}$ ), photochemical production in the Cotonou plume could explain the 70-ppb ozone level. Type IV air masses related to biomass burning emissions can have similar chemical characteristics (although lower $\mathrm{NO}_{\mathrm{x}}$ level) and can be found at similar altitude levels during the WAM period above the Guinea Gulf (Mari et al., 2008; Sauvage et al., 2007a). Indeed the type IV air mass transport pathway is the following: a baroclinic low-level circulations in a 2$\mathrm{km}$ layer at $5^{\circ} \mathrm{S}$ can uplift ozone precursors from the Southern Hemisphere $(\mathrm{SH})$ and fire products are then transported from the SH to the Northern Hemisphere (NH) by the southeasterly trade wind above the monsoon layer. This transport pathway can contributes to a regional $\mathrm{CO}$ increase (e.g. the 170-ppb CO concentrations found upwind of Cotonou), but it cannot explain the sharp gradient in the ozone precursor and ozone concentrations between the air mass upwind and downwind of Cotonou. This is why we beleive that our data set includes an air mass type corresponding to the influence of city plumes.

In order to confirm the sources responsible for the chemical characteristics of each group, one must determine the transport processes associated to the different air masses. This will tell us also if the classification based only on correlation between chemical tracers is a valid approach for West Africa.

\subsection{Air mass transport analysis}

The analysis of the air mass transport was made using the Lagrangian Particle Dispersion Model (LPDM) FLEXPART 

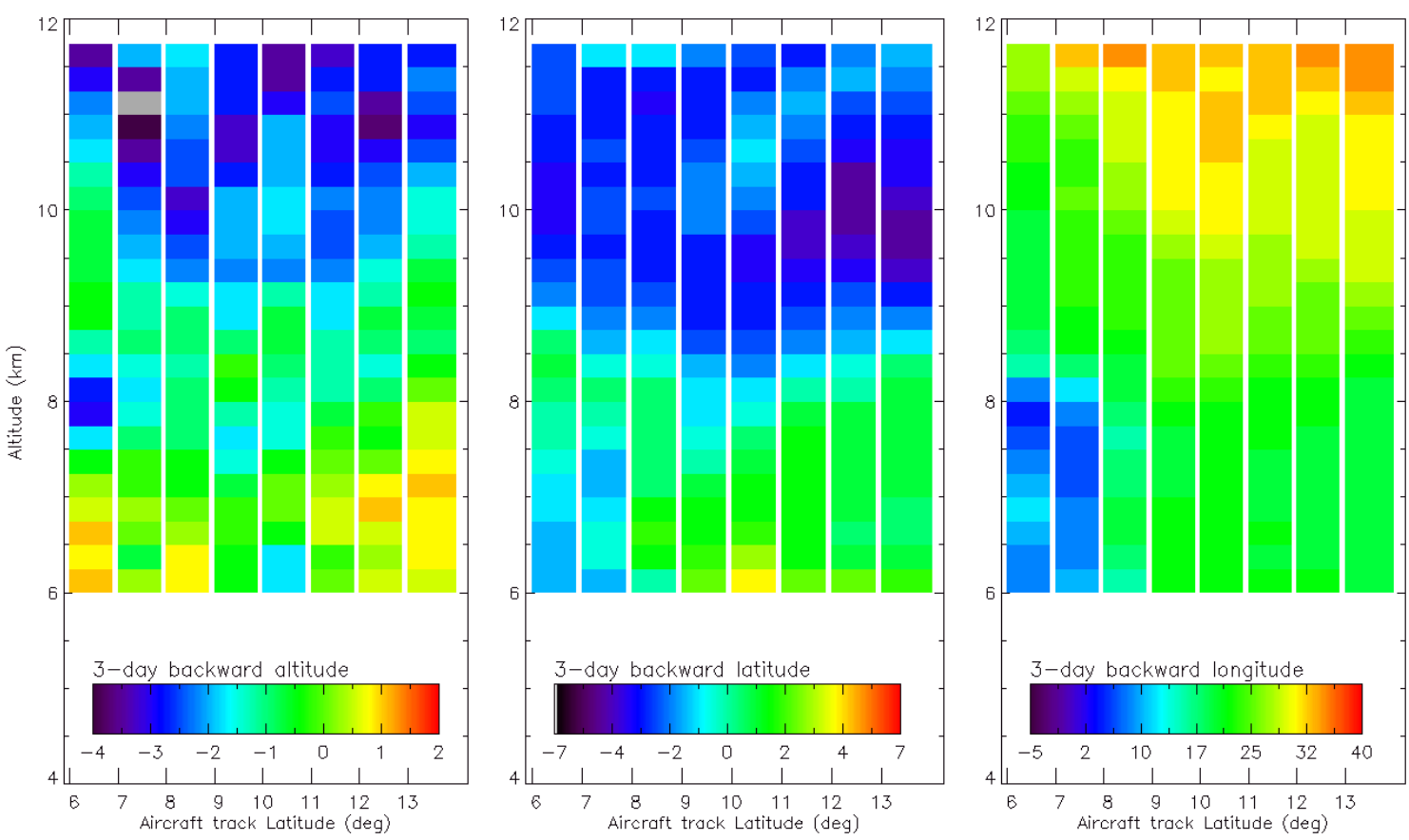

Fig. 5a. Altitude vs. latitude FLEXPART plots of particles released along the 13 August flight track. The color scale indicates the altitude (left in $\mathrm{km}$ ), latitude (middle in ${ }^{\circ}$ ), and longitude (right in ${ }^{\circ}$ ) change of the air mass between the observation time and its position three days before.
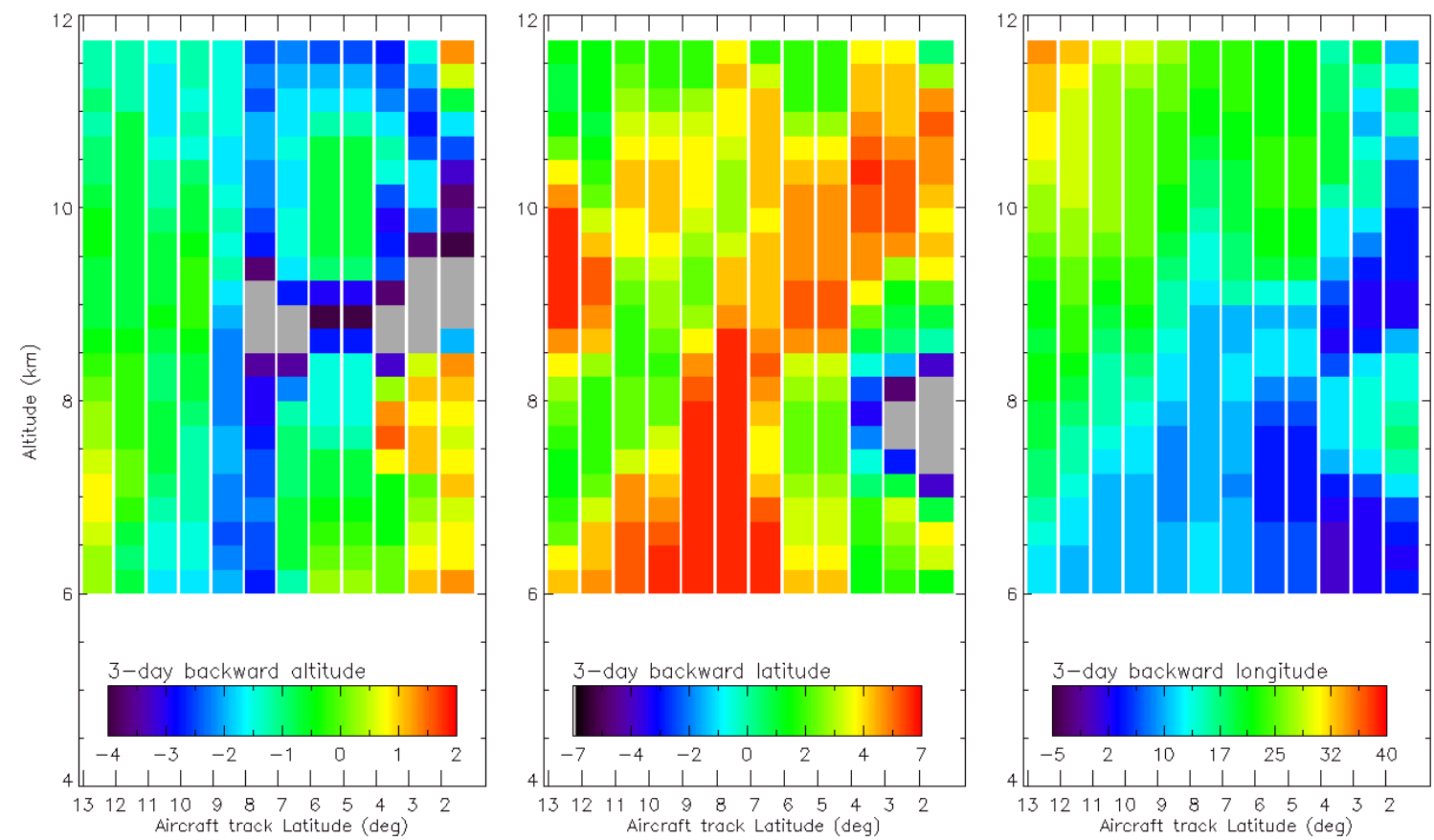

Fig. 5b. Altitude vs. latitude FLEXPART plots of particles released along the 19 August a.m. flight track. The color scale indicates the altitude (left in $\mathrm{km}$ ), latitude (middle in ${ }^{\circ}$ ), and longitude (right in ${ }^{\circ}$ ) change of the air mass between the observation time and its position three days before. 

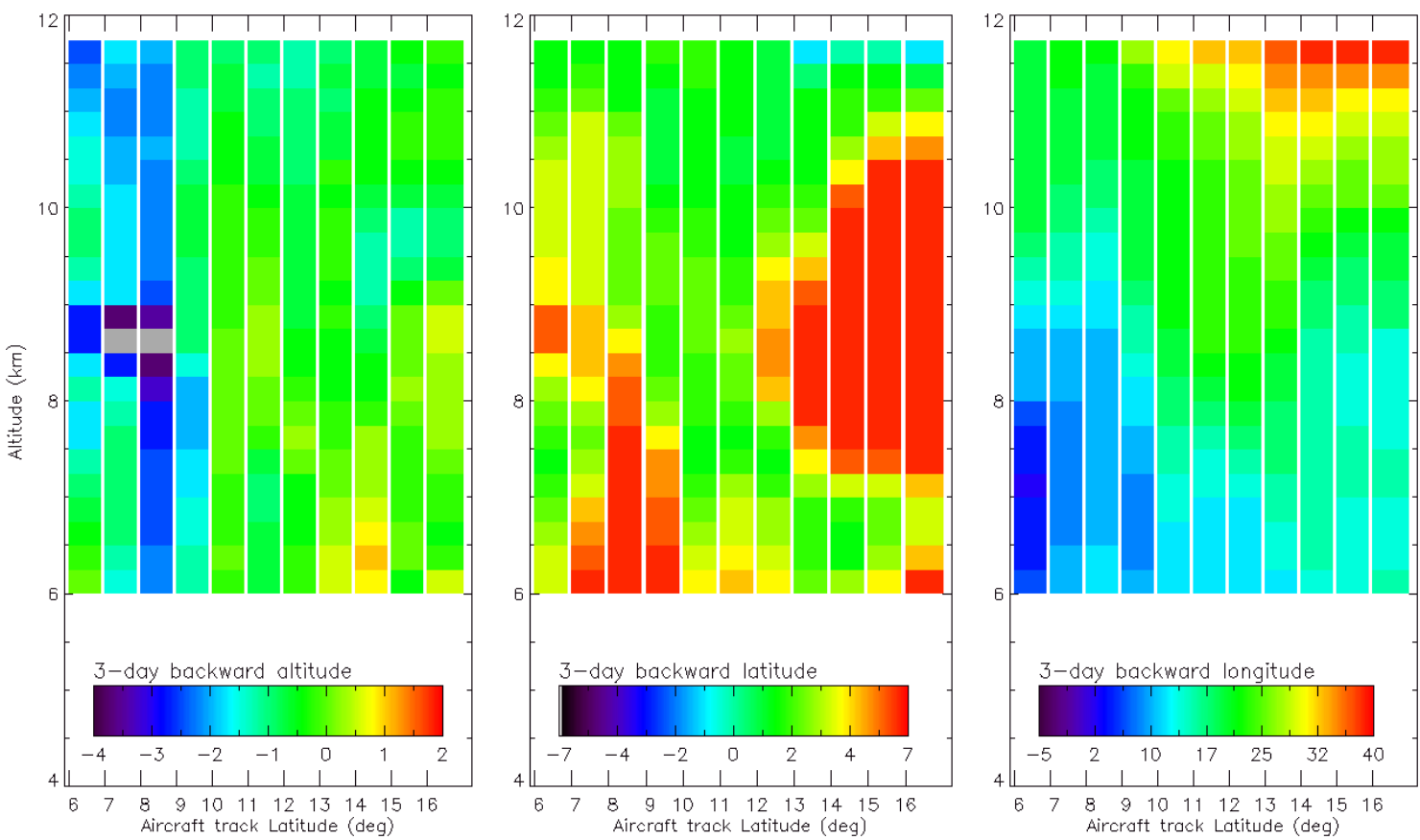

Fig. 5c. Altitude vs. latitude FLEXPART plots of particles released along the 19 August p.m. flight track. The color scale indicates the altitude (left in $\mathrm{km}$ ), latitude (middle in ${ }^{\circ}$ ), and longitude (right in ${ }^{\circ}$ ) change of the air mass between the observation time and its position three days before.
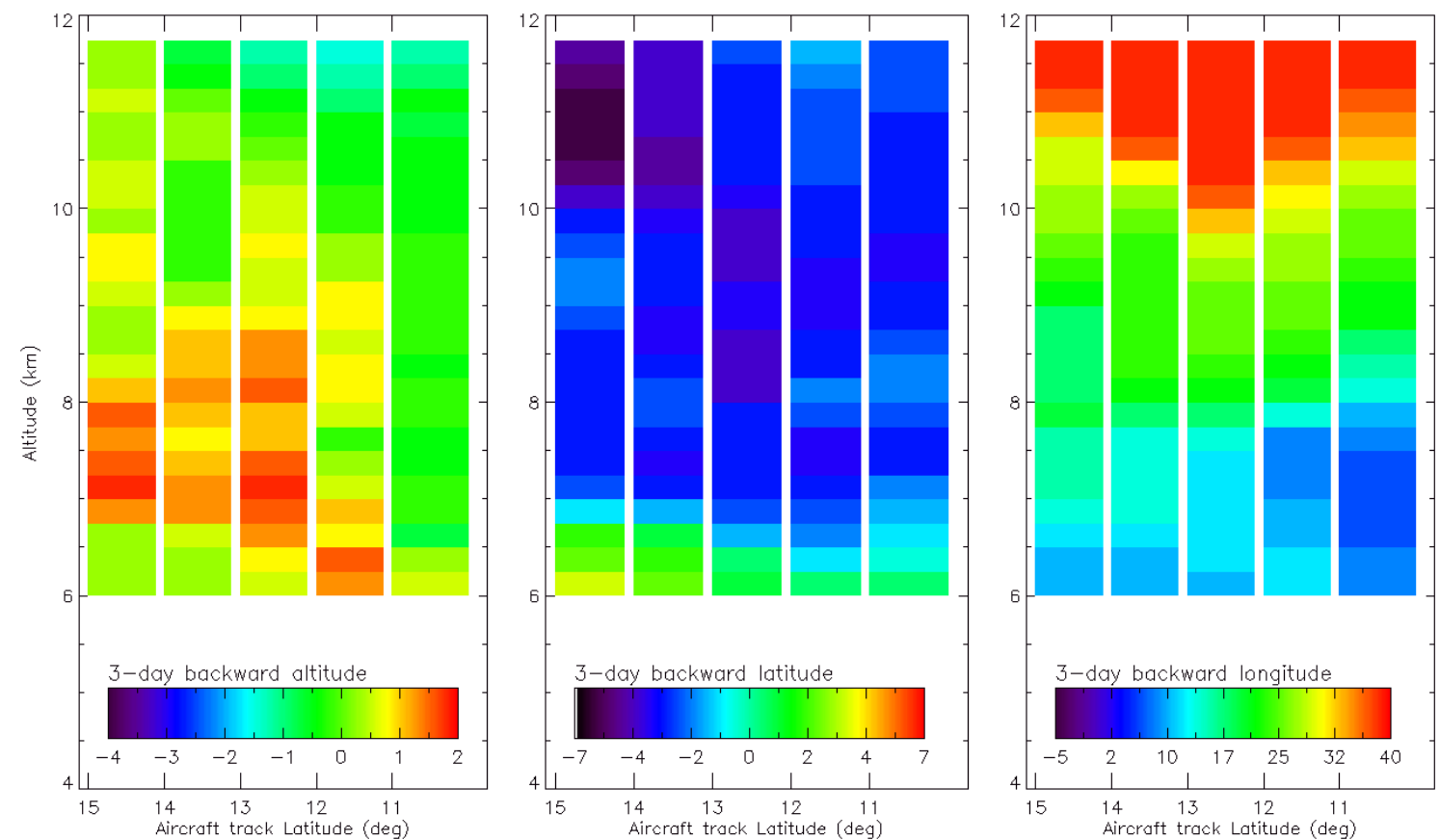

Fig. 5d. Altitude vs. latitude FLEXPART plots of particles released along the 20 August flight track. The color scale indicates the altitude (left in $\mathrm{km}$ ), latitude (middle in ${ }^{\circ}$ ), and longitude (right in ${ }^{\circ}$ ) change of the air mass between the observation time and its position three days before. 
Table 2. Classification of the air masses for the 4 meridional cross-sections.

\begin{tabular}{|c|c|c|c|c|}
\hline Date & $\begin{array}{c}13 \text { August } \\
12: 13-15: 21 \mathrm{UT}\end{array}$ & $\begin{array}{l}19 \text { August a.m. } \\
\text { 09:14-12:08 UT }\end{array}$ & $\begin{array}{l}19 \text { August p.m. } \\
\text { 13:42-16:27 UT }\end{array}$ & $\begin{array}{c}20 \text { August } \\
\text { 14:03-17:30 UT }\end{array}$ \\
\hline $\begin{array}{l}\text { Type I } \\
\text { air } \\
\text { mass }\end{array}$ & $\begin{array}{c}\mathrm{CO}>130 \mathrm{O}_{3}<50 \\
\mathrm{RH}>50 \% \\
11.5 \mathrm{~km}, 6^{\circ}-11^{\circ} \mathrm{N} \\
8 \mathrm{~km}, 6^{\circ} \mathrm{N}\end{array}$ & $\begin{array}{c}\mathrm{CO}>160 \mathrm{O}_{3}<50 \\
\mathrm{RH}>50 \%, \mathrm{NO}_{\mathrm{x}}<0.1 \\
10 \mathrm{~km}, 2^{\circ}-3^{\circ} \mathrm{N}\end{array}$ & & \\
\hline $\begin{array}{l}\text { Type II } \\
\text { air } \\
\text { mass }\end{array}$ & & $\begin{array}{c}\mathrm{CO}<110 \mathrm{O}_{3}>70 \\
\mathrm{RH}<30 \% \mathrm{NO}_{\mathrm{x}}<0.3 \\
10 \mathrm{~km} 11^{\circ}-14^{\circ} \mathrm{N}\end{array}$ & $\begin{array}{c}\mathrm{CO}<110 \mathrm{O}_{3}>70 \\
\mathrm{RH}<30 \% \mathrm{NO}_{\mathrm{x}}<0.5 \\
7-10 \mathrm{~km} 11^{\circ}-14^{\circ} \mathrm{N}\end{array}$ & $\begin{array}{c}\mathrm{CO}<110 \mathrm{O}_{3}>70 \\
\mathrm{RH}<30 \% \mathrm{NO}_{\mathrm{x}}<0.5 \\
7.5 \mathrm{~km} 11.5^{\circ}-14^{\circ} \mathrm{N}\end{array}$ \\
\hline $\begin{array}{l}\text { Type III } \\
\text { air mass }\end{array}$ & & $\begin{aligned} \mathrm{CO} & >200 \mathrm{NO}_{\mathrm{x}}>1 \\
& <4 \mathrm{~km} 6^{\circ} \mathrm{N}\end{aligned}$ & $\begin{aligned} \mathrm{CO} & >200 \mathrm{NO}_{\mathrm{x}}>1 \\
& <4 \mathrm{~km} 6^{\circ} \mathrm{N}\end{aligned}$ & \\
\hline $\begin{array}{l}\text { Type IV } \\
\text { air } \\
\text { mass }\end{array}$ & & $\begin{array}{c}\mathrm{CO} \approx 150 \mathrm{O}_{3} \approx 70 \\
\mathrm{RH}<30 \% \mathrm{NO}_{\mathrm{x}}<0.3 \\
7.5 \mathrm{~km} 2^{\circ}-4^{\circ} \mathrm{N}\end{array}$ & & \\
\hline $\begin{array}{l}\text { Type V } \\
\text { air } \\
\text { mass }\end{array}$ & & $\begin{array}{c}\mathrm{CO} \approx 130 \mathrm{O}_{3} \approx 60 \\
\mathrm{RH}>50 \% \mathrm{NO}_{\mathrm{x}} \approx 0.5 \\
7.5 \mathrm{~km} 4^{\circ}-6^{\circ} \mathrm{N}\end{array}$ & $\begin{array}{c}\mathrm{CO} \approx 110 \mathrm{O}_{3} \approx 60 \\
\mathrm{RH} \approx 80 \% \mathrm{NO}_{\mathrm{x}}>0.7 \\
7.5 \mathrm{~km} 8^{\circ}-10^{\circ} \mathrm{N}\end{array}$ & $\begin{array}{c}\mathrm{CO}<110 \mathrm{O}_{3} \approx 55 \\
\mathrm{RH}>40 \% \mathrm{NO}_{\mathrm{x}}>0.7 \\
5.5 \mathrm{~km} 11^{\circ}-13^{\circ} \mathrm{N}\end{array}$ \\
\hline
\end{tabular}

version 6.2 (Stohl et al., 1998, 2002) driven by 6-hourly ECMWF operational analyses (T106L91) interleaved with operational forecasts every $3 \mathrm{~h}$. The quality of the wind data used for the simulations have been checked using the dropsonde wind data (not shown). The agreement is excellent both for the wind speed and the wind direction, namely the AEJ vertical structure is well reproduced as well as the southerly flow in the monsoon layer. A southeasterly flow (trade wind layer) is also visible in the $700-600 \mathrm{hPa}$ layer above the Gulf of Guinea on 13 August and 19 August.

FLEXPART includes turbulent diffusion, parameterizations of sub-grid scale convection and of topographic processes, as well as online computation of potential vorticity (PV) for each air parcel. For a given simulation 2000 particles were released during $30 \mathrm{~min}$ in a box with a 250 -m vertical thickness and a $1^{\circ} \times 1^{\circ}$ horizontal area. This has been done for 23 boxes at different altitudes from 6 to $11.75 \mathrm{~km}$ (250 $\mathrm{m}$ step) and for different latitudes (every degree) along the vertical cross-section defined by the aircraft flight pattern. Then the positions of the 2000 particles were computed backward in time for 3 days. The 2000 particle mean positions 3 days before the observations are compared to the positions of the observations (released point) in order to produce altitude/latitude plots (Figs. 5a to 5d) of:

- the relative altitude change of the air mass in order to identify significant convective ascent or downward transport from the tropopause region

- the relative latitude change of the air mass to identify, on one hand transport from latitudes $<10^{\circ} \mathrm{N}$, i.e. from regions potentially influenced by biogenic emissions from the forest or even by biomass burning emissions from the $\mathrm{SH}$, and on the other hand from latitudes $>20^{\circ} \mathrm{N}$ i.e. from the subtropics where downward transport from the UTLS is often observed

- the relative longitude change of the air mass to assess the fast zonal transport from regions outside of West Africa i.e. mainly corresponding to influence of long range transport from Asia and the Middle East.

The discussion of these figures will focus on the transport processes related to the air mass groups which have been identified in Sect. 3.1.3 using the aircraft observations.

\section{Type I air mass}

For the 13 August flight (Fig. 5a), the type I air mass at $11.5 \mathrm{~km}$ corresponds to a $3-4 \mathrm{~km}$ uplift according to the FLEXPART simulation and comes from latitudes always less than $10^{\circ} \mathrm{N}$. Upward motion is also resolved by the model for the lower altitude range near $8 \mathrm{~km}$ over Cotonou at $6^{\circ} \mathrm{N}$ with very small horizontal motions. Then vertical transport of pollution sources on the Northern coast of the Guinea gulf (Lagos, oil fields in the Niger delta) is the most likely explanation for the observed large $\mathrm{CO}$ values. Indeed MSG images (not shown) indicate deep convective cells at $6^{\circ} \mathrm{N}$, $6^{\circ}-9^{\circ} \mathrm{E}$ on 10 August 2007 and 11 August 2007. For the 19 August a.m. flight (Fig. 5b), FLEXPART simulations for type I air masses over Gulf of Guinea between 8.5 and $10 \mathrm{~km}$ also show local uplift three days before.

\section{Type II air mass}

On 19 August, the type II air masses observed North of $11^{\circ} \mathrm{N}$ in the morning at $10 \mathrm{~km}$ correspond to advection from 
latitudes $>20^{\circ} \mathrm{N}$. Although no clear subsidence is observed, the strong meridional PV gradient at these latitudes would support the idea of dry intrusion from mid-latitudes for type II air masses (Kowol-Santen and Ancellet, 2000). For the afternoon flight (Fig. 5c), type II air masses are again related to advection from latitudes $>20^{\circ} \mathrm{N}$. The horizontal and vertical extent of the region influenced by this advection between 7 and $10 \mathrm{~km}$ corresponds remarkably well to the large section of this flight influenced by the observations labeled as type II air masses. Finally for the 20 August type II air mass at $7.5 \mathrm{~km}$ (Fig. 5d), the FLEXPART simulation shows a transport pathway which is different from the type II air mass identified on 19 August with a southeasterly flow linking the observation area with eastern Africa at $10^{\circ} \mathrm{N}, 3$ days before. The connection with the UTLS is still possible as there is a downward motion of $500 \mathrm{~m}$ per day. It is also noticeable on this day that the vertical stratification of the air mass origin in Fig. 5d corresponds well to three different air mass types in the observations at $5.5 \mathrm{~km}$ (type V), $7.5 \mathrm{~km}$ (type II) and $12 \mathrm{~km}$ (no specific anomalies for all the parameters, so aged air masses advected by the Tropical Easterly Jet (TEJ)).

\section{Type III air mass}

The differences between Niamey and Cotonou have been noticed in Sect. 3.1.1 and are related to differences in the boundary layer dynamics (land/ocean transition for Cotonou and semi-arid region for Niamey), but also to differences in the lowermost free tropospheric dynamics. Indeed near $\mathrm{Ni}$ amey at the 4-km altitude there is a detrainment layer related to the convergence between the monsoon flow and the Saharan heat low which generally corresponds also to the top of the layer influenced by the AEJ, while near Cotonou the vertical stratification is driven mainly by the southerly flow extending to $3-4 \mathrm{~km}$ and the easterly flow above. The latter corresponds to the northern branch of the southeasterly trade winds. This vertical layering frequently observed during the wet season near $6^{\circ} \mathrm{N}$ along the coast has been discussed by Sauvage et al. (2007a).

To study more specifically the origin or the air mass just above the PBL the 19 August near Cotonou, a 4-day backward FLEXPART simulation was performed in two 500-m thick layers at altitudes of $2.25 \mathrm{~km}$ and $3.75 \mathrm{~km}$. The 2000 particles are grouped into 5 clusters, the positions of which are shown as a function of time for the two layers (Fig. 6). Advection was quite slow in both layers with a weak southwesterly flow and a significant southeasterly transport pathway appears only above $3.5 \mathrm{~km}$ on a 4-day timescale. The long residence time of the air mass above the coast line near Cotonou means that the air mass influenced by biomass burning from the $\mathrm{SH}$ is probably dominated by mesoscale circulations near the coast. Similar effects have been documented at mid-latitudes for pollution transport in large cities located near the sea (Zhang et al., 1998; Drobinski et al., 2007). Hypothesis of a significant influence of local emissions in the ozone production observed near Cotonou is then supported by the trajectory study.

\section{Type IV air mass}

On 19 August the type IV air masses at low latitudes between 2 and $4^{\circ} \mathrm{N}$ near $7.5 \mathrm{~km}$ correspond to air masses coming from the $\mathrm{SH}\left(10^{\circ} \mathrm{S}, 20^{\circ} \mathrm{E}\right)$. Therefore ozone precursors observed in this air mass can be related to the active biomass burning which is very common during the austral winter (Mari et al., 2008). This is also consistent with the high $\mathrm{CO} / \mathrm{NO}_{\mathrm{x}}$ ratio (200) compared to the weaker ratio (20) observed in the type $\mathrm{V}$ air masses. The first evidences of southern hemispheric fire intrusions were described by Sauvage et al. (2005) based on the MOZAIC profiles over Africa. These authors showed that elevated concentrations of ozone observed between 600 and $700 \mathrm{hPa}$ over West Africa during the the wet season originated from fires in the SH. In the framework of the AMMA campaign, regular ozonesoundings were performed at Cotonou, which is located near the Gulf of Guinea and therefore can be influenced by the pollution from the southern hemispheric fires. In Mari et al. (2008), one can note that the ozone peak on the $17 \mathrm{Au}-$ gust Cotonou ozonesounding profile corresponds to the active phase of the African Easterly Jet - South (AEJ-S) when the Gulf of Guinea is under the influence of the fire plumes. Actually, the F-F20 flights period is included in this second active phase of the AEJ-S which goes from 9 August to 31 August.

\section{Type V air mass}

The air mass trajectory analysis is very interesting for the type $\mathrm{V}$ air mass as it is the group where the identification of the sources is the most uncertain. For air mass identified between $4^{\circ} \mathrm{N}$ and $6^{\circ} \mathrm{N}$ near $7.5 \mathrm{~km}$ on 19 August in the morning, the FLEXPART simulation shows a slow horizontal transport. Upward motion is not clearly resolved by FLEXPART for the air mass at $7 \mathrm{~km}$ but is shown for air masses arriving $1.5 \mathrm{~km}$ higher and originating from Northern Nigeria. Notice that the RH vertical stratification revealed by the two dropsondes in this area shows that the $7.5 \mathrm{~km}$ level is at the lower boundary of a very humid layer between 7.5 and $10 \mathrm{~km}$ (see Figs. 7a to $7 \mathrm{~d}$ in next section). So the $\mathrm{O}_{3}$ production in this type $\mathrm{V}$ air mass could be explained by an upward transport of ozone precursors, namely organic compounds from biogenic emissions and by the high $\mathrm{NO}_{\mathrm{x}}$ concentrations related to either lightning and/or $\mathrm{NO}_{\mathrm{x}}$ soil emission. It is difficult to find lightning data matching exactly the air mass positions during their transport through convective systems, but long term ground based monitoring network like ZEUS (see http://sifnos.engr.uconn.edu/) can provide a qualitative estimate of the lightning impact. We have indeed found more frequent flash occurences east of $2^{\circ} \mathrm{E}$ during the period 16 August to 18 August less than three days before 

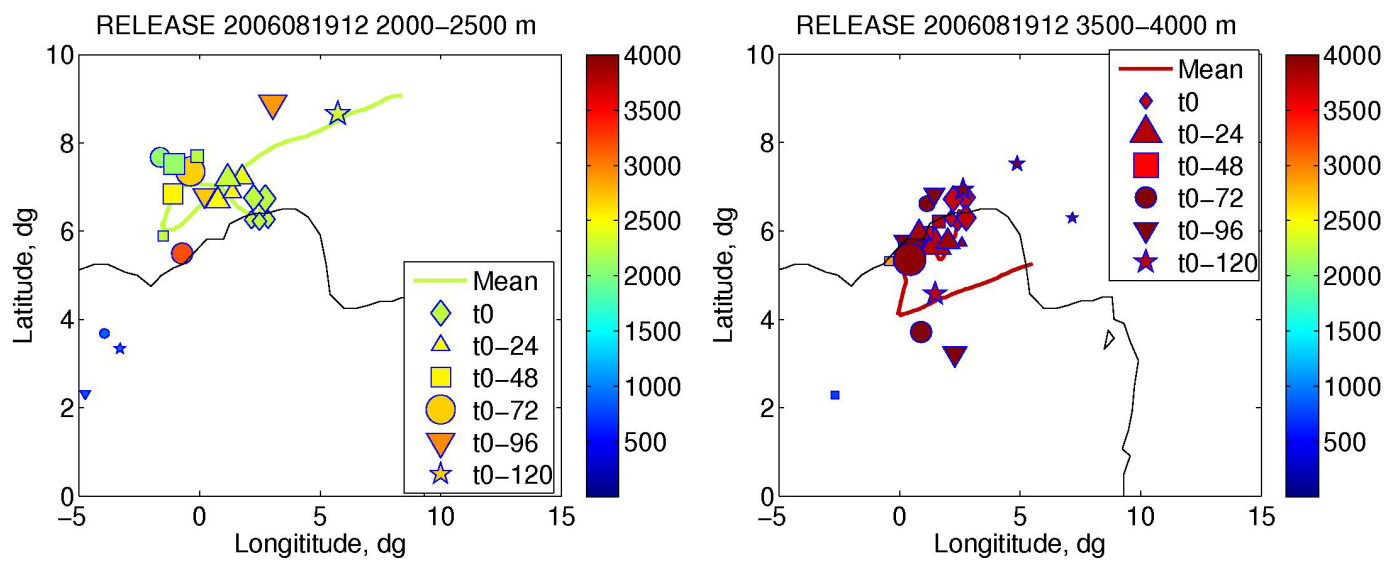

Fig. 6. 5-days FLEXPART backward time position of five clusters of the 2000 particles released between 2 and $2.5 \mathrm{~km}$ (left panel) and between 3.5 and $4 \mathrm{~km}$ (right panel) over Cotonou on 19 August at 12:00 UT. The clusters are plotted every $24 \mathrm{~h}$, the color corresponds to their altitude, and the size of each cluster is proportional to the number of particles.

the measurements of the F-F20. Thus the lightning source cannot be ignored.

During the afternoon flight, the 3-km uplift of air masses located initially from Northern Nigeria is in good agreement with the type $\mathrm{V}$ air mass observed between $8^{\circ} \mathrm{N}$ and $11^{\circ} \mathrm{N}$ at $7.5 \mathrm{~km}$. This area corresponds also to the 4 dropsondes where high RH is observed at many vertical levels between ground and the aircraft (see Figs. 7a to $7 \mathrm{~d}$ in next section). Looking at the comparison of the trajectories for the two type $\mathrm{V}$ air masses of the am and pm flights, it is encouraging to see that they are similar while the two air masses were identified using only chemical tracer data. This demonstrates that the air mass classification in Table 2, which is based on relative impact of different transport processes, is indeed in good agreement with a direct meteorological analysis.

For the type $\mathrm{V}$ air mass at $6 \mathrm{~km}$ from $11^{\circ} \mathrm{N}$ to $13^{\circ} \mathrm{N}$ on 20 August (Fig. 5d), it shows a slow zonal advection and a 1-2 km downward motion over West Africa (air mass at $12^{\circ} \mathrm{E} 3$ days before). Although no indication of upward transport is shown by the FLEXPART simulation, the slow zonal motion increases the probability for encountering convection with uplifting of an air mass. The low CO necessary for this group is explained by the fact that, if convection has occurred, it must have developed over an area with moderate vegetation and little influence from biomass burning emissions. The high $\mathrm{NO}_{\mathrm{x}}$ concentrations and subsequent $\mathrm{O}_{3}$ production characteristic of the type $\mathrm{V}$ air mass must be related to lightning and/or upward transport of soil emissions at latitudes above $10^{\circ} \mathrm{N}$.

\subsection{Variability of the hydroperoxides measurements}

The $\mathrm{H}_{2} \mathrm{O}_{2}$ concentrations are shown in Figs. $7 \mathrm{a}$ to $7 \mathrm{~d}$ together with the relative humidity and the fraction of $\mathrm{H}_{2} \mathrm{O}_{2}$ relative to the total concentration of hydroperoxides (organic peroxides and hydrogen peroxide). The latter parameter is quite useful in the mid and upper troposphere because, for air masses showing a clear decrease of $\mathrm{H}_{2} \mathrm{O}_{2}$ concentrations, it helps to distinguish on one hand the impact of mixing by upper tropospheric air where there is low $\mathrm{ROOH}$ and on the other hand fast convective upward transport of depleted $\mathrm{H}_{2} \mathrm{O}_{2}$ air masses within the monsoon layer where $\mathrm{ROOH}$ will decrease more slowly than $\mathrm{H}_{2} \mathrm{O}_{2}$ in the presence of wet scavenging and aqueous chemistry (Snow et al., 2007). For elevated $\mathrm{H}_{2} \mathrm{O}_{2}$ concentrations, the $\mathrm{H}_{2} \mathrm{O}_{2}$ fraction can measure the atmospheric chemical processing of an air mass which is proportional to the duration of the atmospheric oxidation processes responsible for $\mathrm{OH}$ formation. This will decrease the $\mathrm{H}_{2} \mathrm{O}_{2}$ fraction as the hydrocarbon oxidation will produce organic peroxides (Heike et al., 1996).

Regarding the $\mathrm{H}_{2} \mathrm{O}_{2}$ vertical distribution, there is a negative vertical gradient in the free troposphere with a maximum near $2 \mathrm{~km}(1.5-1.8 \mathrm{ppb})$ and lowest values ranging from 200 to $500 \mathrm{ppt}$ near $10 \mathrm{~km}$. Below $2 \mathrm{~km}, \mathrm{H}_{2} \mathrm{O}_{2}$ concentrations decrease with a significant sink related to wet scavenging and surface removal. Looking more precisely at the free tropospheric data, the $\mathrm{H}_{2} \mathrm{O}_{2}$ concentrations show a sharp drop near $7 \mathrm{~km}$ with concentrations often being above $1 \mathrm{ppb}$ below $7 \mathrm{~km}$ and decreasing below $600 \mathrm{ppt}$ above $8 \mathrm{~km}$. This is in good agreement with previous observations over the ocean (Heike et al., 1996; Snow et al., 2007) showing that it is the direct result of a large production of $\mathrm{HO}_{\mathrm{x}}$ and $\mathrm{RO}_{2}$ at altitudes near $2-4 \mathrm{~km}$.

Following Heike et al. (1996), a positive correlation is expected between $\left[\mathrm{O}_{3}\right]^{*}\left[\mathrm{H}_{2} \mathrm{O}\right] /[\mathrm{CO}]$ and $\left[\mathrm{H}_{2} \mathrm{O}_{2}\right]$ since $\mathrm{OH}$ will be proportional to the ratio $\left[\mathrm{O}_{3}\right]^{*}\left[\mathrm{H}_{2} \mathrm{O}\right] /[\mathrm{CO}]$. Since the photochemical time scale for $\mathrm{H}_{2} \mathrm{O}_{2}$ is short enough (1-2 days), this correlation will hold as long as recent vertical transport and related wet scavenging in the PBL cannot compete with the net photochemical equilibrium. In Fig. 8, the correlation 

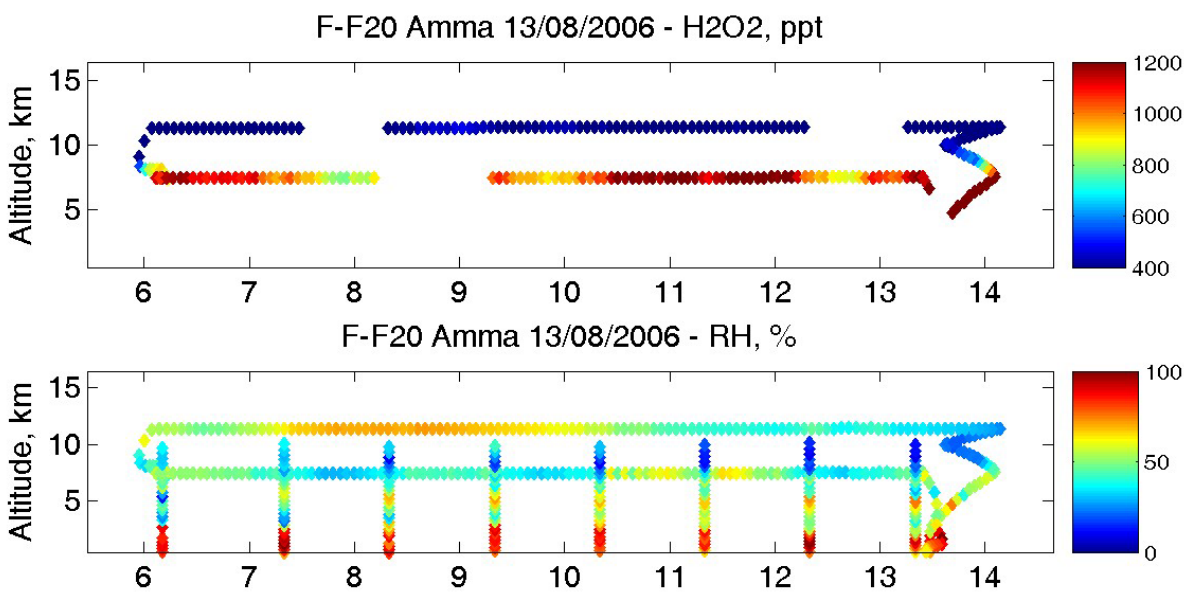

F-F20 Amma 13/08/2006 - H2O2*100/(H2O2+ROOH), \%

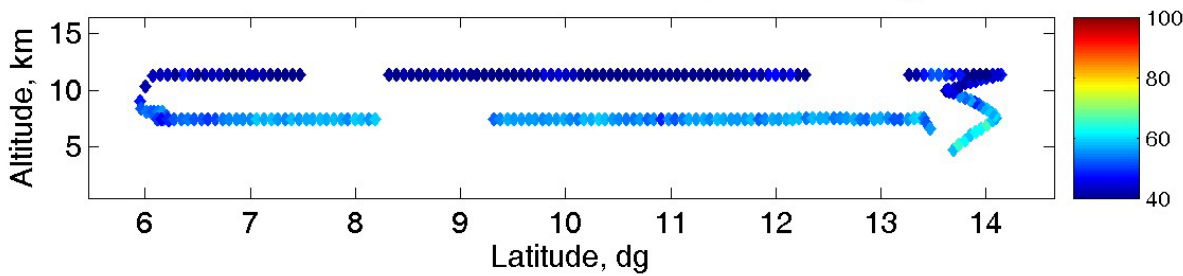

Fig. 7a. Altitude vs. latitude distribution of $\mathrm{H}_{2} \mathrm{O}_{2}$ mixing ratio in ppt, relative humidity in $\%$ and fraction of $\mathrm{H}_{2} \mathrm{O}_{2}$ over total organic peroxides in $\%$ along the 13 August flight.
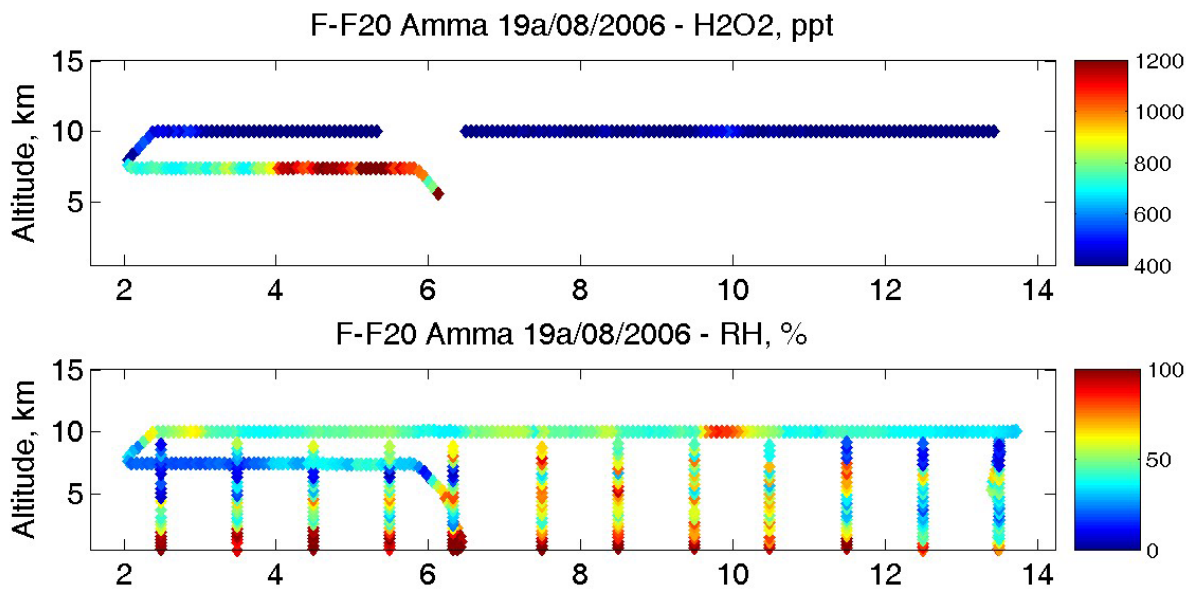

F-F20 Amma 19a/08/2006 - H2O2*100/(H2O2+ROOH), \%

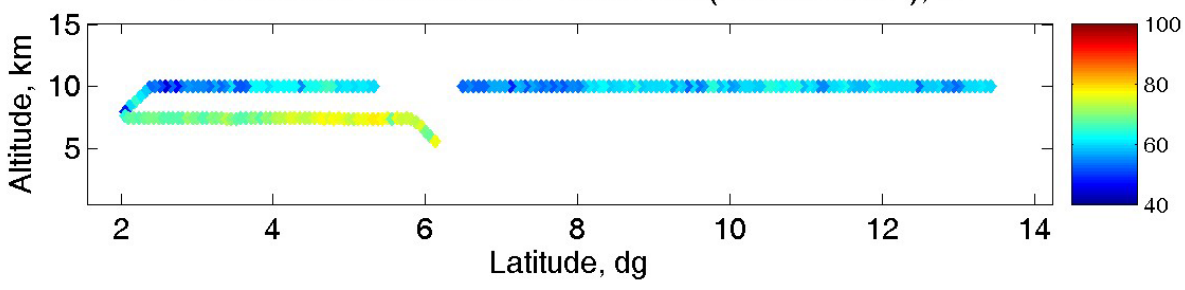

Fig. 7b. Altitude vs. latitude distribution of $\mathrm{H}_{2} \mathrm{O}_{2}$ mixing ratio in ppt, relative humidity in $\%$ and fraction of $\mathrm{H}_{2} \mathrm{O}_{2}$ over total organic peroxides in \% along the 19 August a.m. flight. 

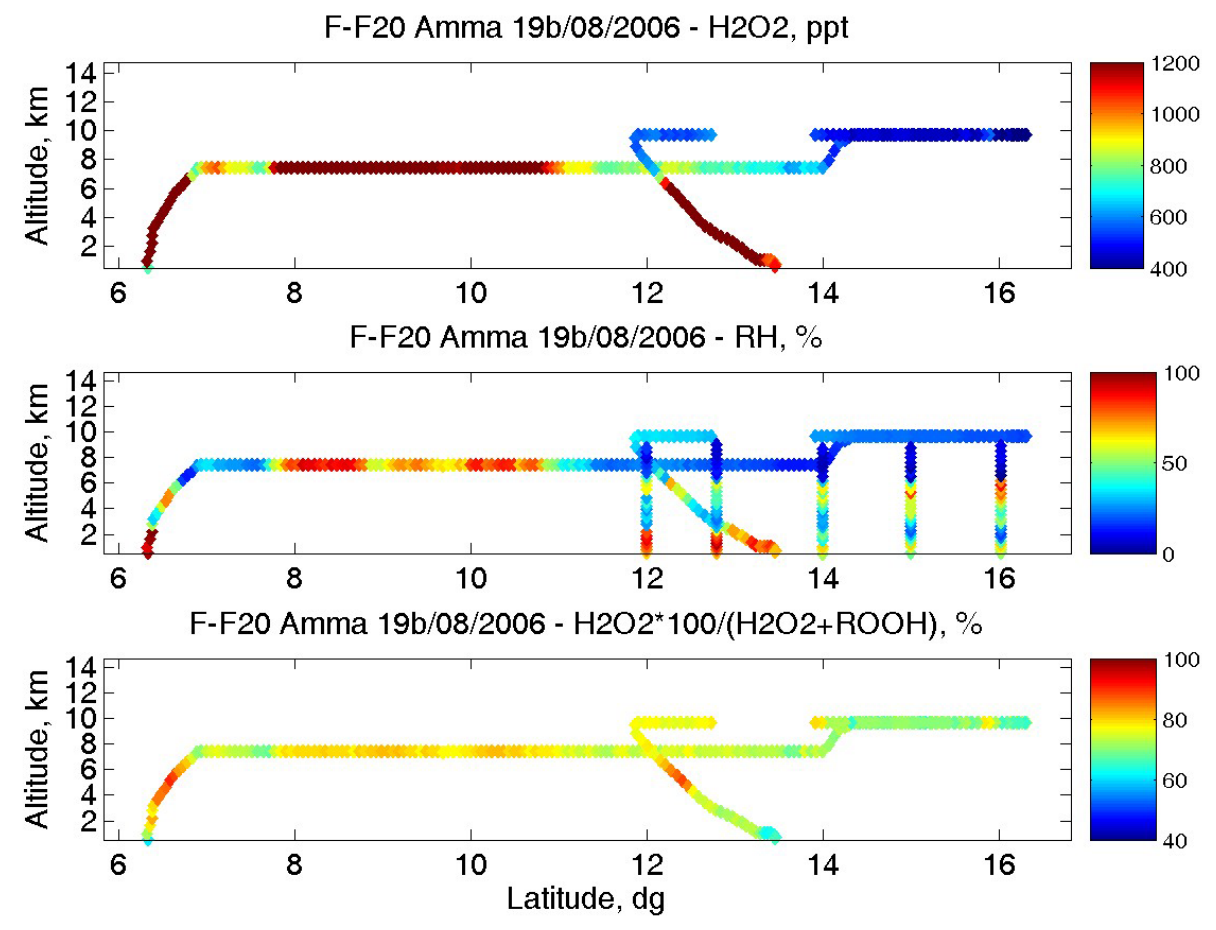

Fig. 7c. Altitude vs. latitude distribution of $\mathrm{H}_{2} \mathrm{O}_{2}$ mixing ratio in ppt, relative humidity in $\%$ and fraction of $\mathrm{H}_{2} \mathrm{O}_{2}$ over total organic peroxides in $\%$ along the 19 August p.m. flight.

F-F20 Amma 20/08/2006 - H2O2, ppt
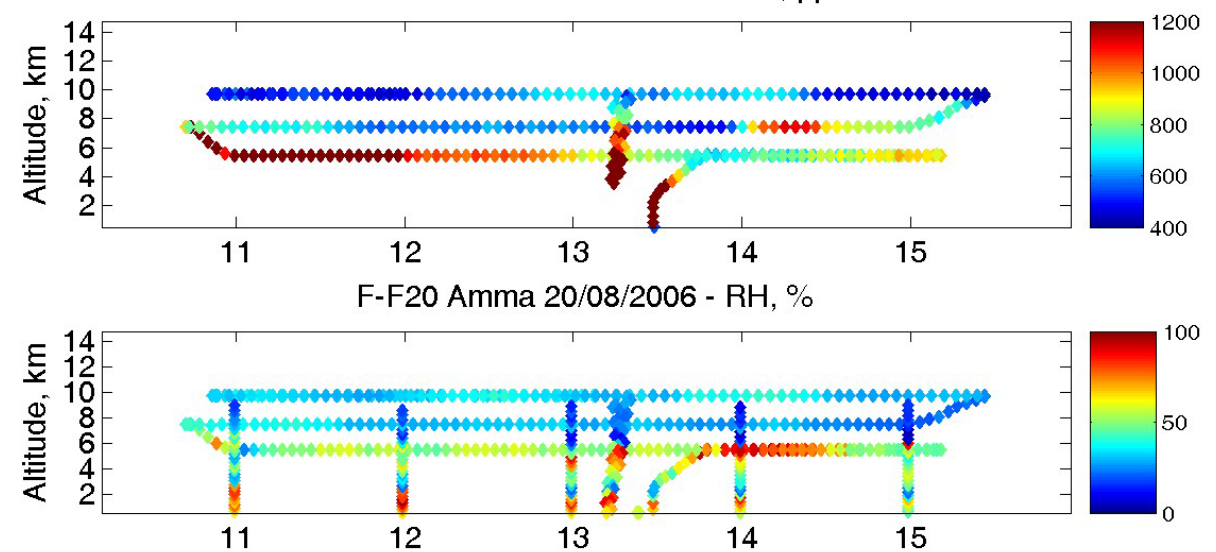

F-F20 Amma 20/08/2006 - H2O2*100/(H2O2+ROOH), \%

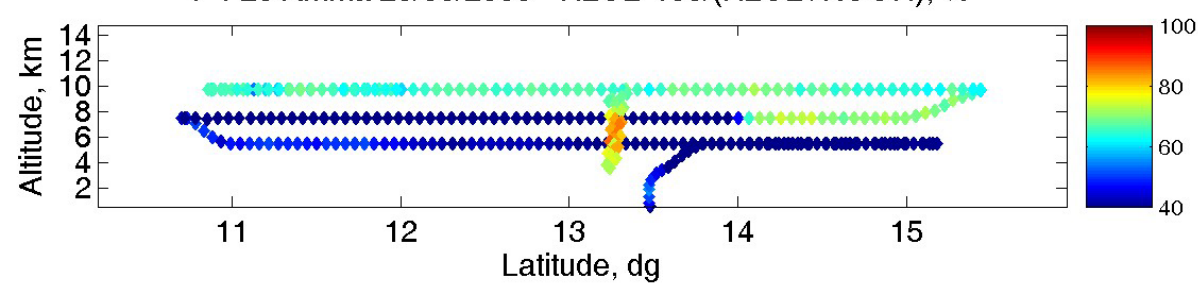

Fig. 7d. Altitude vs. latitude distribution of $\mathrm{H}_{2} \mathrm{O}_{2}$ mixing ratio in ppt, relative humidity in $\%$ and fraction of $\mathrm{H}_{2} \mathrm{O}_{2}$ over total organic peroxides in $\%$ along the 20 August flight. 
plot shows that the positive correlation is kept although it is less compact as the ratio $\left[\mathrm{O}_{3}\right]^{*}\left[\mathrm{H}_{2} \mathrm{O}\right] /[\mathrm{CO}]$ increases. Indeed air masses related to a recent vertical transport correspond to a small fraction of the observed data (mainly type I air mass) and it cannot control the correlation plot. It was different for the correlation between $\mathrm{CO}$ and $\mathrm{O}_{3}$ because they have longer photochemical time scales in the free troposphere and a larger fraction of the data collected in West Africa during the wet season may have been influenced by upward transport on a time scale of 1-2 weeks. The decrease in the compactness of the plot are for the highest values of $\left[\mathrm{H}_{2} \mathrm{O}\right]$ in the troposphere $(3-6 \mathrm{~km})$ where the ages of the air masses are largest and the range of $\mathrm{H}_{2} \mathrm{O}_{2}$ concentrations depends on the air mass composition following air mass transport. For example an increase of $\mathrm{NO}_{\mathrm{x}}$ and a decrease of soluble carbonyl compounds will reduce the $\mathrm{H}_{2} \mathrm{O}_{2}$ formation. This dependence of hydrogen peroxide data with the influence of convective transport is then very useful in the discussion of the link between the air mass types identified in Sect. 3.1.3 and the dynamical processes.

\section{Type I air mass}

Considering type I air masses, this study shows that low $\mathrm{H}_{2} \mathrm{O}_{2}$ concentrations $(<500 \mathrm{ppt})$ are related to these air masses, this is consistent with the efficient wet scavenging and/or reaction of $\mathrm{H}_{2} \mathrm{O}_{2}$ with $\mathrm{SO}_{2}$ related to recent uplifting by well developed MCS. The $\mathrm{H}_{2} \mathrm{O}_{2}$ fraction is on the order of 0.4 lower than the fraction for other air masses with similar $\mathrm{H}_{2} \mathrm{O}_{2}$ concentrations $\left(\mathrm{H}_{2} \mathrm{O}_{2}\right.$ fraction near 0.8$)$. Indeed this corresponds to the lower solubility of $\mathrm{ROOH}$ which is less depleted than $\mathrm{H}_{2} \mathrm{O}_{2}$ during convective uplifting.

\section{Type II air mass}

For the type II air mass observed in the upper troposphere, $\mathrm{H}_{2} \mathrm{O}_{2}$ is as low as the concentrations observed for type I air mass. This can be explained by the low water vapor concentrations which cannot maintain elevated $\mathrm{HO}_{\mathrm{x}}$ radical and $\mathrm{H}_{2} \mathrm{O}_{2}$ production. Regarding the $\mathrm{H}_{2} \mathrm{O}_{2}$ fraction, the values are larger than for type I air masses This is in good agreement with the fact that type II air masses could correspond to advection of upper tropospheric air from the subtropics. Indeed in this case mixing with upper tropospheric air dominates the other sinks of hydrogen peroxide.

\section{Type IV air mass}

In previous papers (Lee et al., 1997; Snow et al., 2007), the possibility of hydroperoxide formation in biomass burning plumes have been shown, especially for $\mathrm{H}_{2} \mathrm{O}_{2}$. This is not observed in our study where concentrations of $\mathrm{H}_{2} \mathrm{O}_{2}$ remain near $700-800 \mathrm{ppt}$ at $7.5 \mathrm{~km}$. It is explained by the fact that the time scale for the transport of SH biomass burning near the coast of West Africa is longer than 1-2 days. Indeed in this case, the $\mathrm{H}_{2} \mathrm{O}_{2}$ produced within the plume does

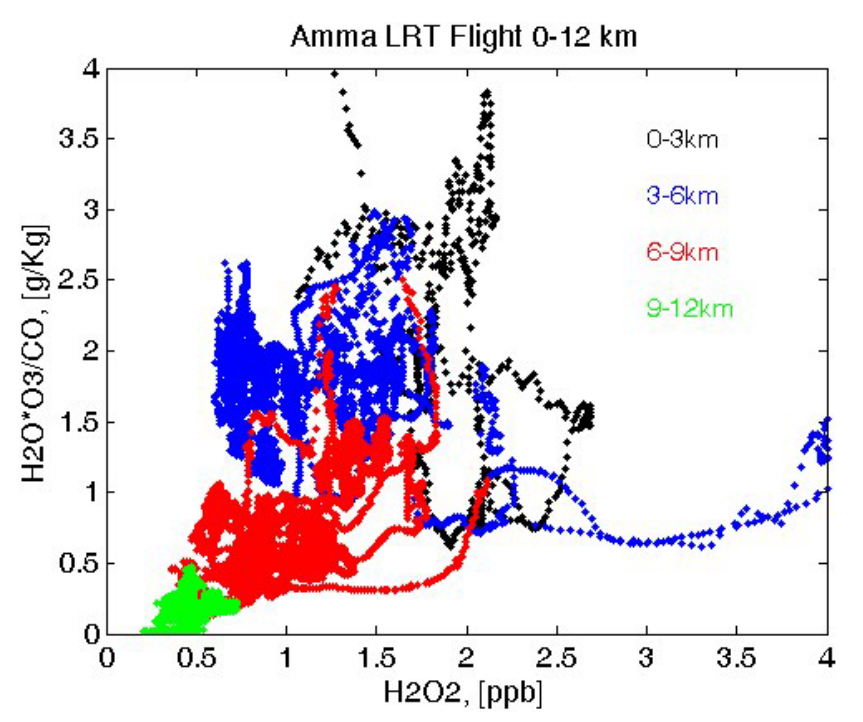

Fig. 8. Scatter plot of $\left[\mathrm{H}_{2} \mathrm{O}\right] *\left[\mathrm{O}_{3}\right] /[\mathrm{CO}]$ in $\mathrm{g} / \mathrm{kg}$ vs. $\mathrm{H}_{2} \mathrm{O}_{2}$ in ppt as measured by the F-F20 during for the four LRT flights. The measurements are colored with altitude (4 classes with a 3-km thickness within the range to $0-12 \mathrm{~km}$ ).

not contribute anymore to the hydroperoxide budget. The $\mathrm{H}_{2} \mathrm{O}_{2}$ fraction is below 0.7 consistent with moderate atmospheric processing being able to increase the formation of $\mathrm{ROOH}$. Thus, it appears that the time scale for the transport of biomass burning cannot exceed 3-4 days.

\section{Type V air mass}

The horizontal variability of $\mathrm{H}_{2} \mathrm{O}_{2}$ near $7.5 \mathrm{~km}$ shows that the higher values $(>1 \mathrm{ppb})$ are often observed in the type $\mathrm{V}$ air mass where high $\mathrm{NO}_{\mathrm{x}}$ and $\mathrm{RH}>50 \%$ are present. This indicates that upward transport plays a significant role in type $\mathrm{V}$ air mass. Uplift of a humid air mass from the lower troposphere increases the $\mathrm{HO}_{\mathrm{x}}$ radical production necessary for subsequent hydroperoxide formation. Since we expect $\mathrm{H}_{2} \mathrm{O}_{2}$ removal in the humid PBL, this implies that the observations correspond to convective processes older than at least 1-2 days, i.e. the time scale for hydrogen peroxide chemical production. It is often the case for the flights discussed in this section since they have been performed in clear air far away from convective systems. Considering that the lifetime of $\mathrm{NO}_{\mathrm{x}}$ is longer in the free troposphere than the hydrogen peroxide lifetime, this hypothesis is also in good agreement with the elevated $\mathrm{NO}_{\mathrm{x}}$ concentrations resulting from either lightning processes in the convective system or upward transport of soil emissions which are maximum over wet continental surfaces (Delon et al., 2008; Stewart et al., 2008). It is also interesting to examine the $\mathrm{H}_{2} \mathrm{O}_{2}$ fraction for the type $\mathrm{V}$ air mass where there is this relative $\mathrm{H}_{2} \mathrm{O}_{2}$ enhancement. We notice high fractions $(>75 \%)$ on 19 August while the fraction drops to $50 \%$ on 20 August. This means that atmospheric 

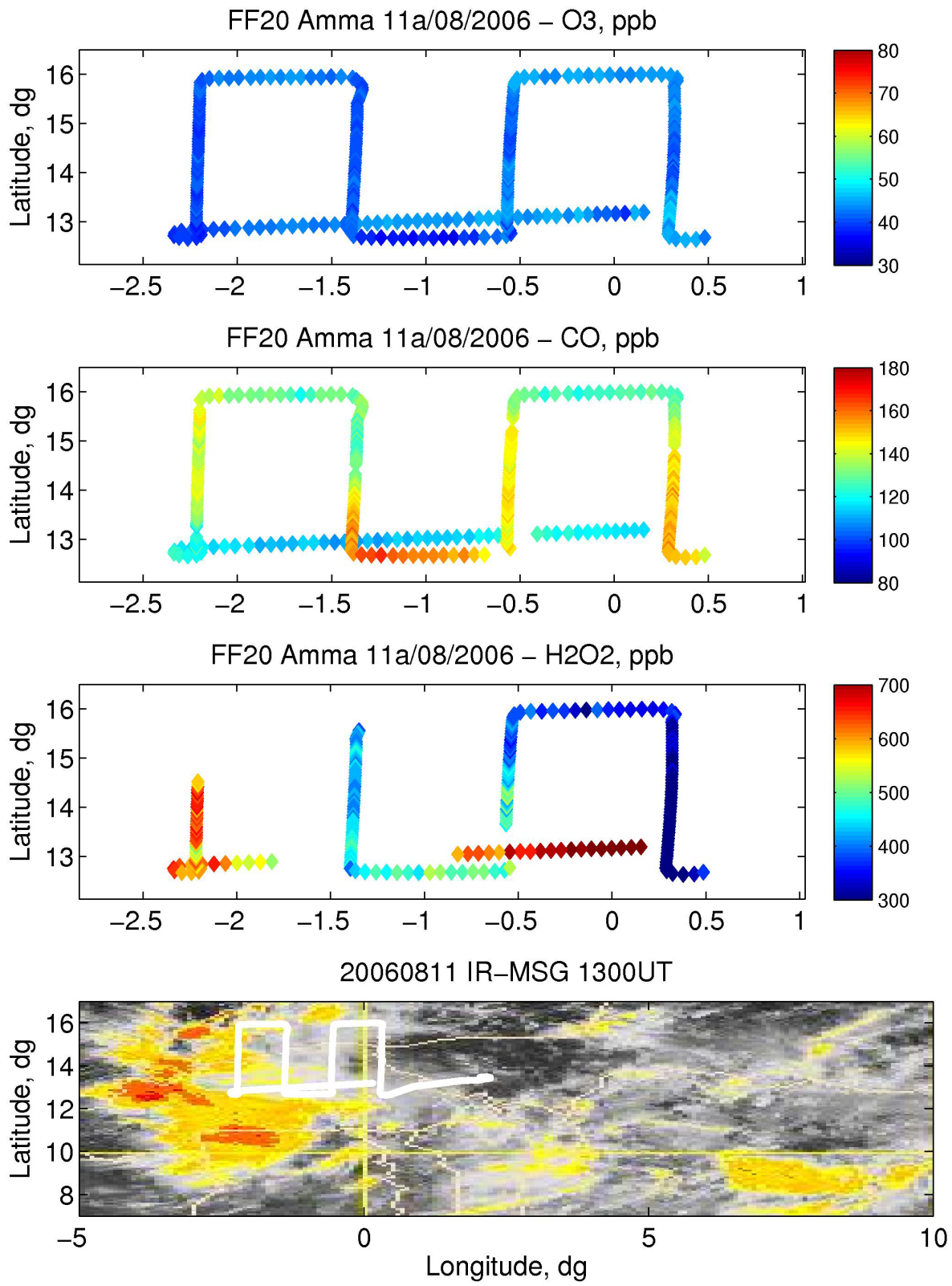

Fig. 9. Latitude vs. longitude distribution of $\mathrm{O}_{3}, \mathrm{CO}$ in ppb, and $\mathrm{H}_{2} \mathrm{O}_{2}$ in ppt along the 11 August MCS flight. The track has been superimposed on the MSG/Meteosat picture taken at the beginning of the flight.

chemical processing during the upward transport has been more intense for the 20 August type $\mathrm{V}$ air mass compared to the 19 August type $\mathrm{V}$ air mass. This is also consistent with lower $\mathrm{RH}$ and $\mathrm{NO}_{\mathrm{x}}$ values on 20 August. Indeed a longer time since exposure to surface emissions and uplifting, allows on one hand dehydration of the air mass in the upper troposphere before subsidence to lower altitudes near $8 \mathrm{~km}$ and on the other hand $\mathrm{NO}_{\mathrm{x}}$ chemical conversion to PAN or nitric acid. We also notice that the trajectory analysis shows more evidence of nearby upward motions for the 19 August type $\mathrm{V}$ air masses.

\section{Comparison of the MCS flight}

\subsection{Chemical composition of the MCS outflow}

Four Mesoscale Convective Systems (MCS) have been studied using the F-F20 aircraft: 3 over the Sahelian region (11 August, 14 August, 17 August) and 1 over the Benin forest (15 August). The F-F20 tracks are superimposed on the images of the MCS brightness temperatures at the times when the F-F20 starts the MCS upper altitude exploration (Figs. 9 to 12 ). The measurements always start at the western bound 

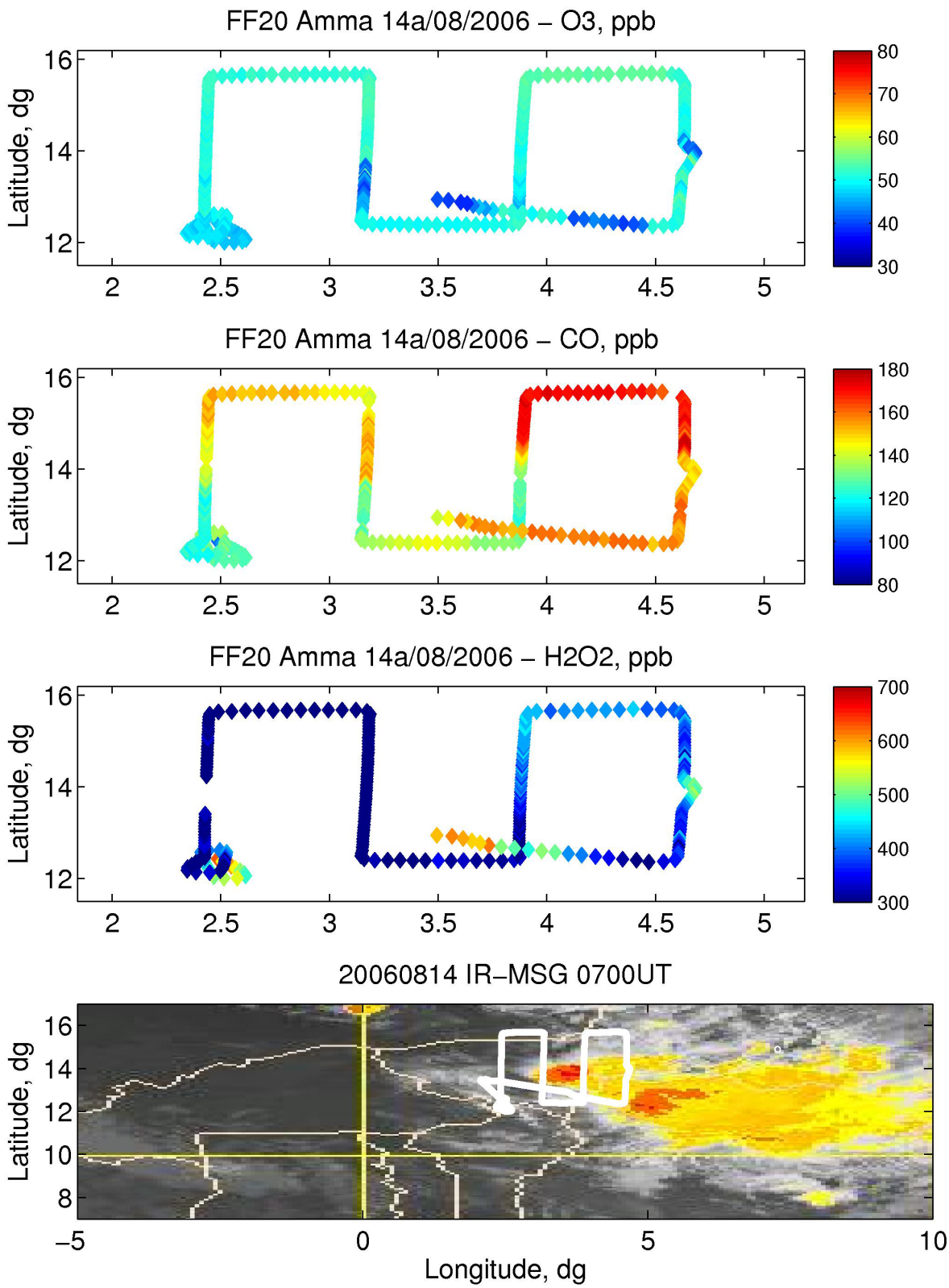

Fig. 10. Latitude vs. longitude distribution of $\mathrm{O}_{3}, \mathrm{CO}$ in ppb, and $\mathrm{H}_{2} \mathrm{O}_{2}$ in ppt along the 14 August MCS flight. The track has been superimposed on the MSG/Meteosat picture taken at the beginning of the flight.

of the M shape flight track and the aircraft stays at the the same altitude $(12 \mathrm{~km})$ during the $2.3 \mathrm{~h}$ upper altitude exploration. So during the flight, the MCS moves westward by approximately $1.5^{\circ}$ from its initial position shown in Figs. 9 to 12 .

\section{MCS characteristics}

On 11 August, the upward development revealed by MSG images indicates a strong MCS which formed 2 days before over the border between Nigeria and Chad $\left(10^{\circ} \mathrm{N}, 15^{\circ} \mathrm{E}\right)$ and was followed by a second one that dissipated east of Niamey. The aircraft has flown mainly in the outflow region of the first MCS after its transport northward to Western Niger. On 14 August, another strong MCS was studied East of Niamey with the beginning of the flight being near the leading edge of the MCS and the end in the convective area. The MCS is significantly younger than the previous one as it started only $15 \mathrm{~h}$ before the F-F20 flight, over the Zinder region $\left(14^{\circ} \mathrm{N}\right.$, $10^{\circ} \mathrm{E}$ ) before moving westward at the same latitude. On 15 August, the MCS is located at latitudes farther south $\left(10^{\circ} \mathrm{N}\right)$ 

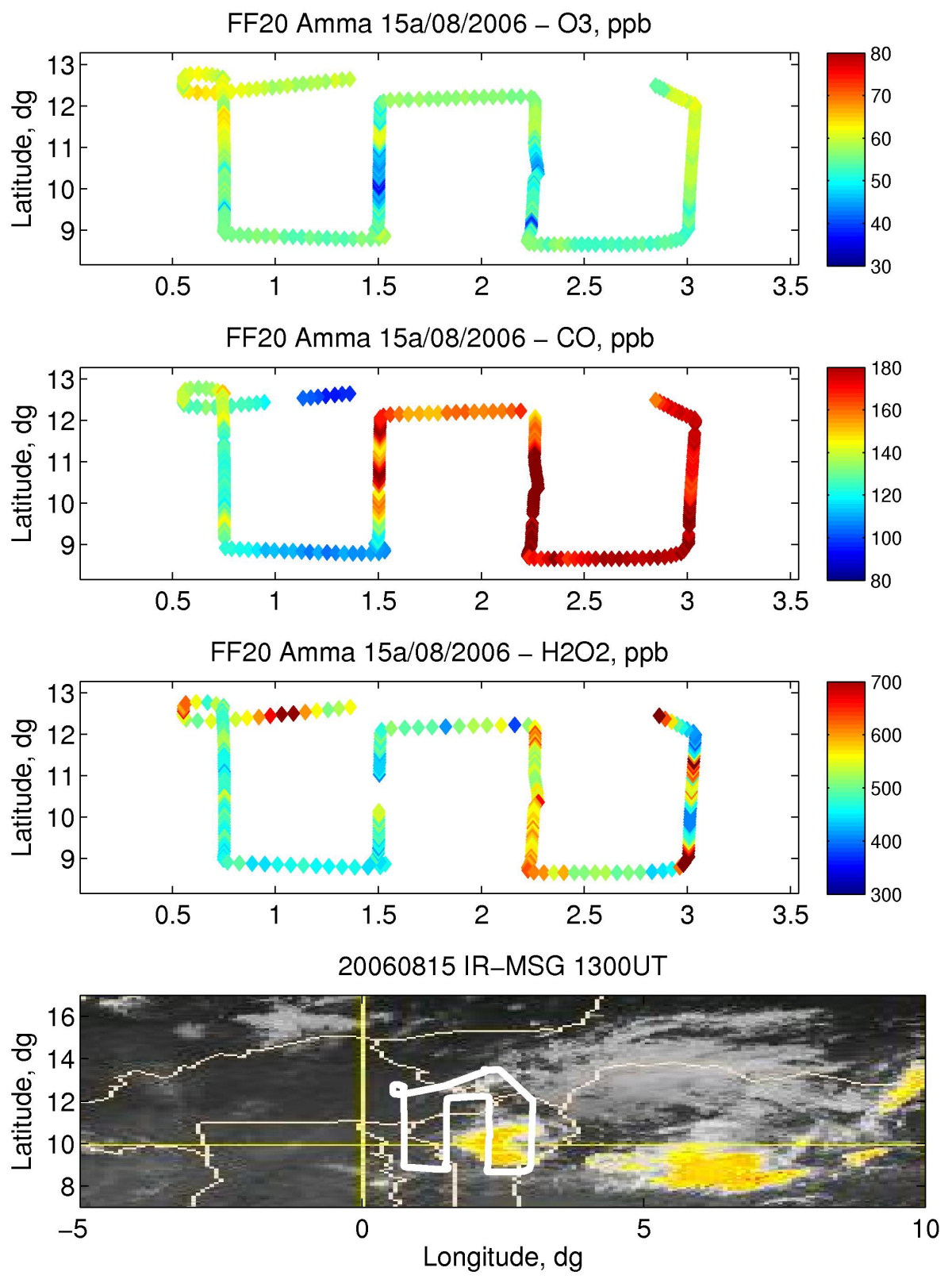

Fig. 11. Latitude vs. longitude distribution of $\mathrm{O}_{3}, \mathrm{CO}$ in ppb, and $\mathrm{H}_{2} \mathrm{O}_{2}$ in ppt along the 15 August MCS flight. The track has been superimposed on the MSG/Meteosat picture taken at the beginning of the flight.

over Benin and it is significantly smaller than the previous ones. It corresponds to the southern tip of a decaying system which formed over Chad $\left(15^{\circ} \mathrm{N}, 17^{\circ} \mathrm{E}\right) 36 \mathrm{~h}$ before. Again the beginning of the flight took place in front of the MCS and the end in the outflow. Finally on 17 August, the MCS is also rather weak during the measurement period over $\mathrm{Ni}$ amey. It actually dissipated during the aircraft deployment with the beginning of the flight in the leading edge of MCS and the end in the convective area. The system formed over the Airr region $\left(18^{\circ} \mathrm{N}, 6^{\circ} \mathrm{E}\right) 18 \mathrm{~h}$ before the F-F20 flight and moved southward to Niamey. Let us examine the horizontal variability of the measured chemical species in the outflow of these MCSs.

\section{Ozone and $\mathrm{CO}$ variability}

Three flights (15 August, 14 August, 11 August) show large sections of the MCS outflow with CO concentrations higher than $140 \mathrm{ppb}$ and up to $190 \mathrm{ppb}$ on 15 August. At the same time, ozone concentrations are always weak $(<50 \mathrm{ppb})$ except on 15 August when they exceed $50 \mathrm{ppb}$ mainly in the 

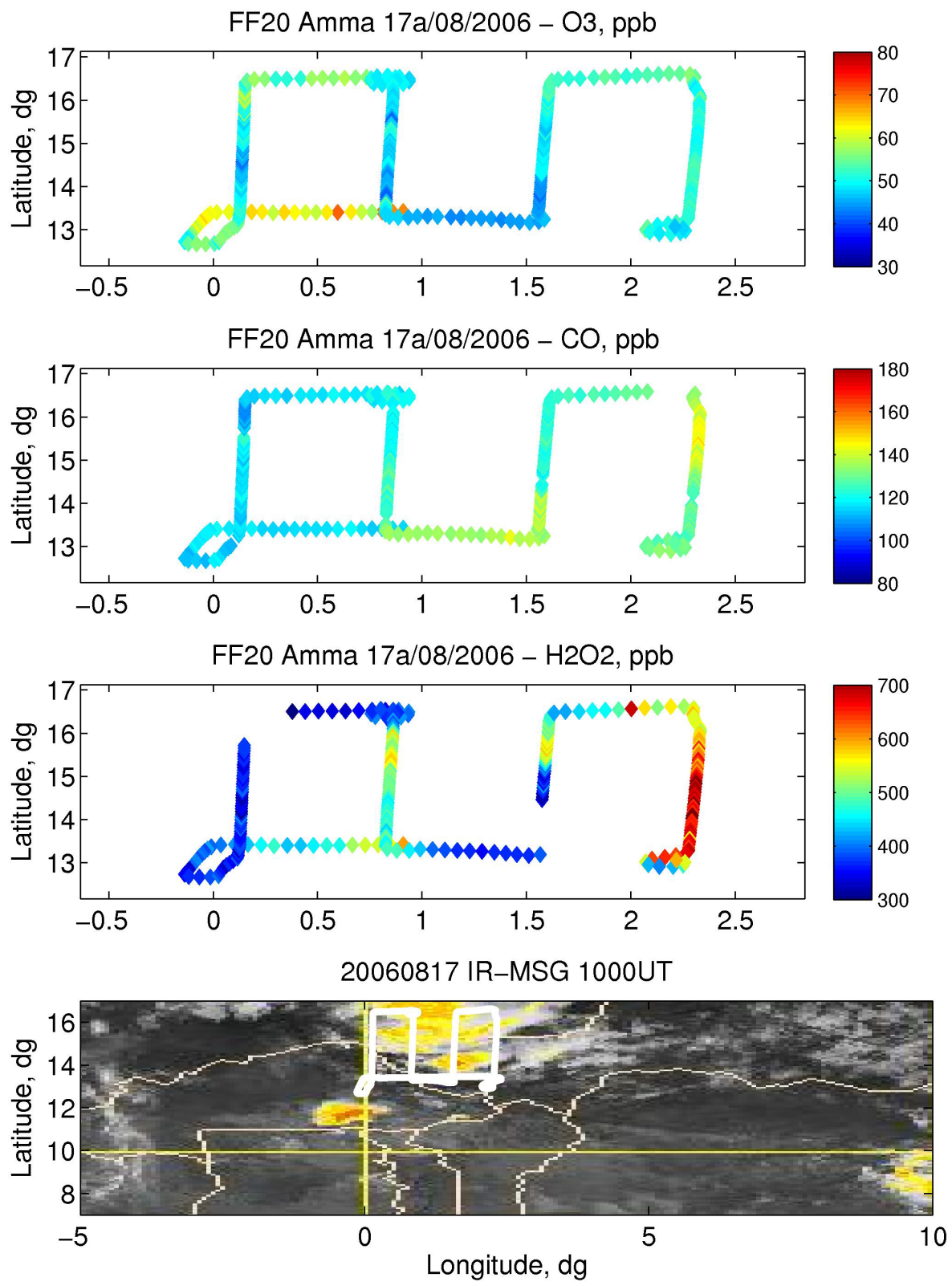

Fig. 12. Latitude vs. longitude distribution of $\mathrm{O}_{3}, \mathrm{CO}$ in ppb, and $\mathrm{H}_{2} \mathrm{O}_{2}$ in ppt along the 17 August MCS flight. The track has been superimposed on the MSG/Meteosat picture taken at the beginning of the flight.

northern part of the convective area. These $\mathrm{CO}$ rich air masses are different from the type I air masses defined earlier as there are directly found in the MCS outflow and at latitudes north of $10^{\circ} \mathrm{N}$. They will be named as type VI air masses hereafter. The question arises whether the $\mathrm{CO}$ enhancement is related to transport of CO surface emissions uplifted from the West African PBL or whether the elevated $\mathrm{CO}$ is already present in the type VI air mass because of long range transport from regions outside the AMMA region. On 17 August, the CO concentrations never exceed $140 \mathrm{ppb}$ and are then lower than the ones measured in the other MCSs. On 15 August and 17 August, the areas with the highest CO values are found behind the convective system in its outflow rather than in its leading edge. This points toward a significant role of the convective transport rather than regional scale circulation on the large concentrations encountered. It is less obvious for the 14 August where the high CO concentrations are located in the northern part of the measurement area, which is less influenced by the MCS outflow. 


\section{Hydroperoxide variability}

The $\mathrm{H}_{2} \mathrm{O}_{2}$ distributions show areas of high concentrations (>600 ppt) but their horizontal extent are always smaller than the high CO patterns. Looking at the average concentrations over the whole convective area, the concentrations are smaller (300-400 ppt) for the most active MCS on 11 August and 14 August. This is consistent with the hydrogen peroxide sink in the humid PBL before rapid upward transport at upper altitudes by the convective system. This hypothesis is also supported by the low values of the $\mathrm{H}_{2} \mathrm{O}_{2}$ fraction $(<50 \%)$ also observed for these two flights since one expect $\mathrm{ROOH}$ to be less depleted in the humid PBL. The only small area with large $\mathrm{H}_{2} \mathrm{O}_{2}$ during the 11 August flight is found in the southwestern corner with also low $\mathrm{H}_{2} \mathrm{O}_{2}$ fraction and moderate $\mathrm{CO}$ concentrations $\approx 120 \mathrm{ppb}$. This would indicate that this particular part of the MCS convective area has been influenced by a significant amount of atmospheric processing to increase $\mathrm{ROOH}$. It is not so surprising that old masses are interleaved with fresh convective outflow in the older MCS. The very important role of $\mathrm{ROOH}$ in the $\mathrm{HO}_{\mathrm{x}}$ budget of the upper tropical troposphere has already been discussed in the work of Prather and Jacob (1997).

The $\mathrm{H}_{2} \mathrm{O}_{2}$ concentrations are in the range of $500-600 \mathrm{ppt}$ for the less active MCS on 15 August and 17 August. The $\mathrm{H}_{2} \mathrm{O}_{2}$ fraction remains high for the layer with the largest $\mathrm{H}_{2} \mathrm{O}_{2}$ concentrations (>600 ppt) on these two days. This would be consistent with an upward transport from the humid PBL which took place 1 or 2 days before the measurement to allow some $\mathrm{H}_{2} \mathrm{O}_{2}$ production with significant $\mathrm{ROOH}$ increase compared to $\mathrm{H}_{2} \mathrm{O}_{2}$.

To summarize the analysis of the $\mathrm{CO}, \mathrm{O}_{3}$ and $\mathrm{H}_{2} \mathrm{O}_{2}$ concentrations shows that convective transport drives the variability of the chemical composition when they are intercompared. The main key parameters appear to be the lifetime and the latitudinal position of the MCS during its evolution. Indeed one first notices no influence of polluted air mass on 17 August due to the northern origin of the MCS. Second, regarding the 11 August and 15 August MCS, transport from the lower layers at latitudes around $10^{\circ} \mathrm{N}$ may explain the large CO concentrations found in type VI air masses. The latter conclusion is based on the observation of a negative latitudinal CO gradient by other aircraft in the lower layers Reeves et al. (2009). Third, the lifetime of the MCS allows for more $\mathrm{H}_{2} \mathrm{O}_{2}$ production meaning significant $\mathrm{HO}_{\mathrm{x}}$ radicals formed in the outflow of a long lived MCS. To support this interpretation of the observed comparison of the 4 MCS, it is necessary to conduct an analysis of the air mass transport using the meteorological analysis. For example, this would help to understand why there are large $\mathrm{CO}$ concentrations on 14 August while the MCS has remained above $13^{\circ} \mathrm{N}$ during its lifetime or why there are larger $\mathrm{O}_{3}$ concentrations for the 15 August MCS compared to the 11 August MCS.

\subsection{Air mass transport analysis}

The analysis of the air mass transport was made using again FLEXPART version 6.2 driven by 6-hourly ECMWF analyses (T106L91). For a given simulation 1500 particles were released during $60 \mathrm{~min}$ in a box with a $1-\mathrm{km}$ vertical thickness and a $1^{\circ} \times 1^{\circ}$ horizontal area. This has been done for approximately 17 boxes at $12 \mathrm{~km}$ a.s.l. (i.e. the altitude of the MCS survey flight) and for different latitudes and longitudes (every degree) along the aircraft track. Owing to the limited area of the MCS survey and the limited horizontal resolution of the ECMWF analysis, the variability of the trajectories for a given flight is rather small and is not really suitable for a detailed analysis of mesoscale structure in the chemical composition. However the comparison of the trajectories from one MCS to the other one is possible. So we have focused our attention on a single trajectory computed from a single position in the outflow of the MCS.

First the 4 FLEXPART trajectories ending at $12 \mathrm{~km}$ near the center of the observation area can be compared (Fig. 14). It is interesting to observe that a significant fraction of particles have been uplifted by more than $5 \mathrm{~km}$ in the FLEXPART simulations for the type VI air mass i.e. for the 3 days with high CO in the MCS outflow. FLEXPART is then able to reproduce some convective transport in this region. Part of this transport is already resolved in the ECMWF analysis itself since it remains when the FLEXPART convection is switched off. The cluster in the lower layers indicate a source region located above the Arabic Peninsula 5 days before and with a likely connection further ahead with the Persian Gulf. Notice that this connection is not present on 17 August when CO remains low around the MCS. The question arise about the influence of the significant emissions related to the oil industry in this region. This transport pathway is different from the one analyzed in Barret et al. (2008), where MLS UTLS CO observations first adjusted towards a climatological tropical profile have been assimilated. At and above $150 \mathrm{hPa}$ the main contributors are westward transport by the Tropical Easterly Jet and the Asian Monsoon Anticyclone of Asian polluted air masses that have been uplifted up to $100 \mathrm{hPa}$ resulting in maxima $\mathrm{CO}$ concentrations over North Africa around $25^{\circ} \mathrm{N}$. Even if FLEXPART is able to resolve some uplifting, it may miss strong upward transport due to MCSs encountered along the trajectories. To account for this contribution to the CO distribution, occurrence of observed MCS by MSG was searched along the FLEXPART trajectories. Examples of the cluster positions are shown on the top of MSG images at 00:00 UT on the measurement day and 00:00 UT on the previous day in Fig. 13. This analysis has shown that for the 11 August and 14 August MCS, another MCS encountered previously must have changed the chemical composition of the advected air mass, while for the 15 August and $17 \mathrm{Au}-$ gust MCS it is the influence of the MCS sampled by the aircraft which must be taken into account. Assuming, that the MCS occurrence connects efficiently the lower troposphere 

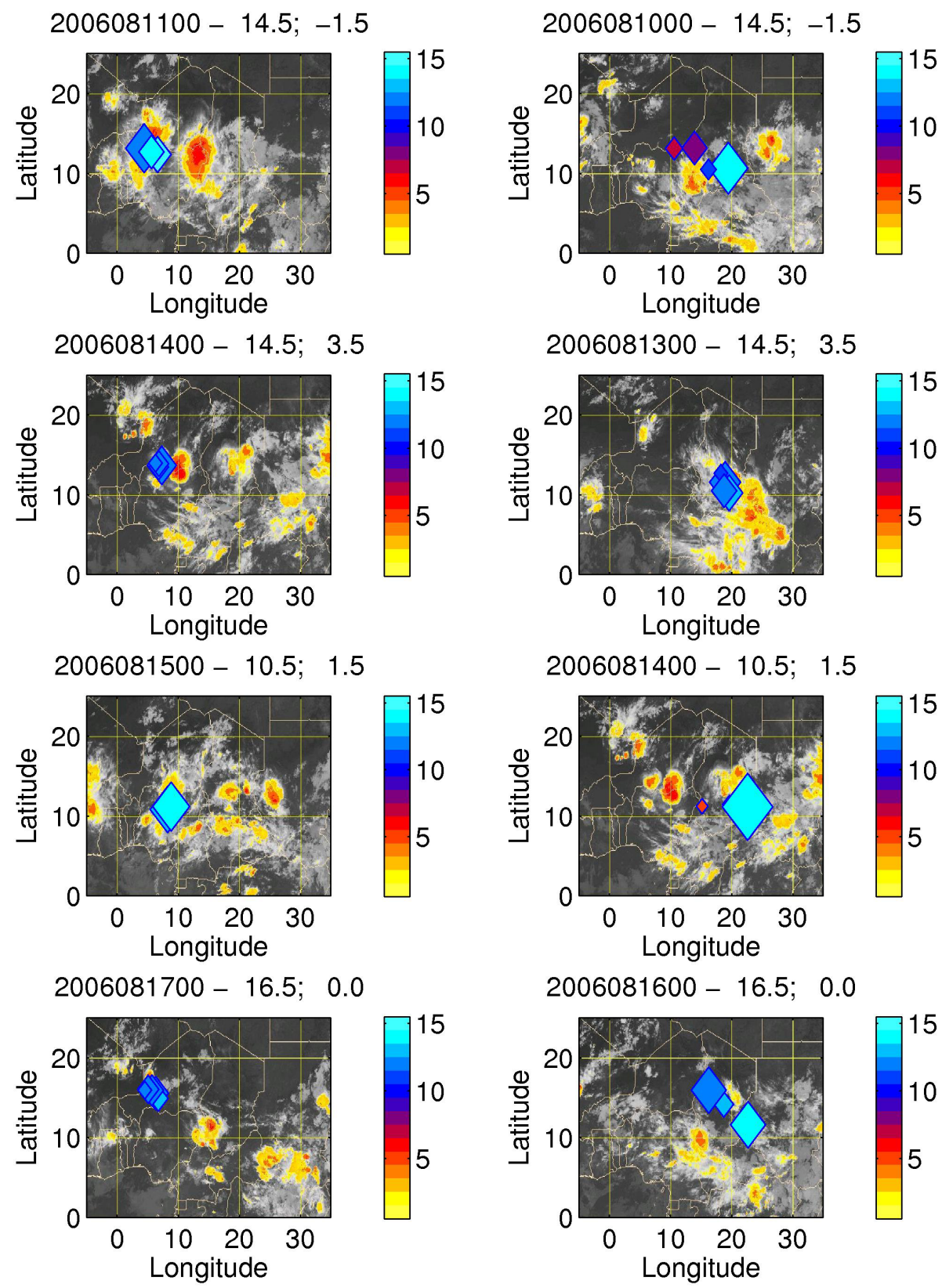

Fig. 13. Plot on MSG/meteosat pictures of the five FLEXPART clusters released at the center of the upper altitude flight track survey around the MCS studied on 11 August, 14 August, 15 August and 17 August (top to bottom). Cluster position and altitude (color code) are given at 00:00 UT on the measurement day (left) and 00:00 UT on the previous day (right). The size of each cluster is proportional to the number of particles.

below $2 \mathrm{~km}$ and the upper troposphere above $10 \mathrm{~km}$, we calculated a backward flexpart simulation releasing 1500 particles at the base of the MCS, i.e. in a $1^{\circ} \times 1^{\circ}$ box between 1.5 and $2 \mathrm{~km}$, at the time when the upper altitude trajectory encounters the MCS. This low level backward simulation was performed on the MCS encountered respectively on $10 \mathrm{Au}$ gust at $10^{\circ} \mathrm{N}, 15^{\circ} \mathrm{E}$ and on 13 August $10^{\circ} \mathrm{N}, 20^{\circ} \mathrm{E}$ for the 11 August and 14 August cases, while it was performed for the sampled MCS at 00:00 UT on the measurement day for the 15 August and 17 August cases. Looking at Fig. 15, it shows that a significant fraction of the 1500 particles are coming from the equatorial region below $6^{\circ} \mathrm{N}$ for the $3 \mathrm{MCS}$ corresponding to the elevated $\mathrm{CO}$ observed by the aircraft in the upper troposphere. More precisely, the fractions of particles south of the $6^{\circ} \mathrm{N}$ limit are respectively $10 \%, 19 \%$ and $34 \%$ for the 11 August, 14 August and 15 August observations. 

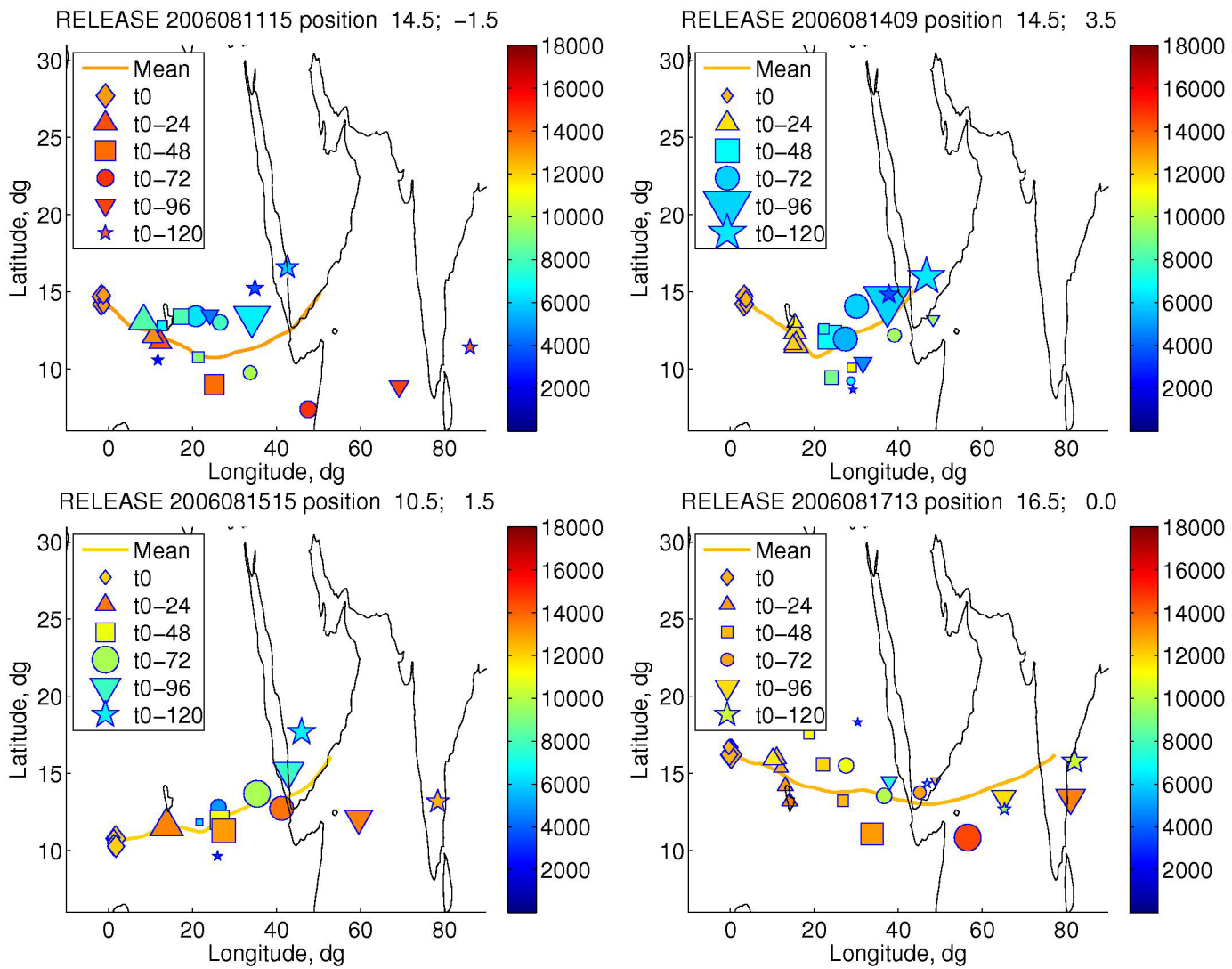

Fig. 14. 5-days FLEXPART backward time position of five clusters of the 2000 particles released at the center of the upper altitude flight track survey around the MCS studied on 11 August (upper left), 14 August (upper right), 15 August (lower left) and 17 August (lower right). The clusters are plotted every $24 \mathrm{~h}$, the color corresponds to their altitude, and the size of each cluster is proportional to the number of particles.

The numbers are even higher $(55 \%, 50 \%$ and $35 \%)$ if we choose the $10^{\circ} \mathrm{N}$ limit which often corresponds to the largest $\mathrm{CO}$ meridional gradient. This implies that the biomass burning source in the $\mathrm{SH}$ contributes to the $\mathrm{CO}$ distribution in the $\mathrm{NH}$ upper troposphere as far as $15^{\circ} \mathrm{N}$. This is in agreement with Barret et al. (2008) who showed that below $150 \mathrm{hPa}$, convective uplift of air masses impacted by biomass burning in Southern Africa within the West African Monsoon region between $0^{\circ} \mathrm{N}$ and $12^{\circ} \mathrm{N}$ is the main contributor to the latitudinal CO maximum. A similar interaction between the two hemispheres is discussed in Edwards et al. (2003) for the dry season, as already mentioned in the introduction. The fact that the largest $\mathrm{O}_{3}$ concentrations are found for the $15 \mathrm{Au}$ gust MCS indicates also that this pathway is probably the dominant one. Indeed the 15 August case corresponds to the largest fraction of particles south of $6^{\circ} \mathrm{N}$, while it is not very different from the other MCS looking at the middle east pathway revealed by the upper level trajectories (Fig. 14).

\section{Conclusions}

In this paper, we have presented the airborne measurements of tropospheric $\mathrm{O}_{3}, \mathrm{CO}, \mathrm{NO}_{\mathrm{x}}, \mathrm{H}_{2} \mathrm{O}$ and hydroperoxide above West Africa during the summer monsoon season. Two different aircraft missions have been planned to study both (1) the efficiency of vertical transport by MCSs with flights at constant altitude $(12 \mathrm{~km})$ in the MCSs vicinity and (2) the remaining influence of convection during the dry spell periods with meridional exploration of the free troposphere between the Gulf of Guinea and the Sahel region at $15^{\circ} \mathrm{N}$. The observed variability of the chemical composition during the meridional transects was used to sort air masses into 5 types:

- convective uplift of polluted air masses by industrial and urban emissions along the coast (type I) and of air masses influenced by biogenic emissions over the continent (type V),

- meridional transport of upper tropospheric air from the subtropical barrier region (type II), 

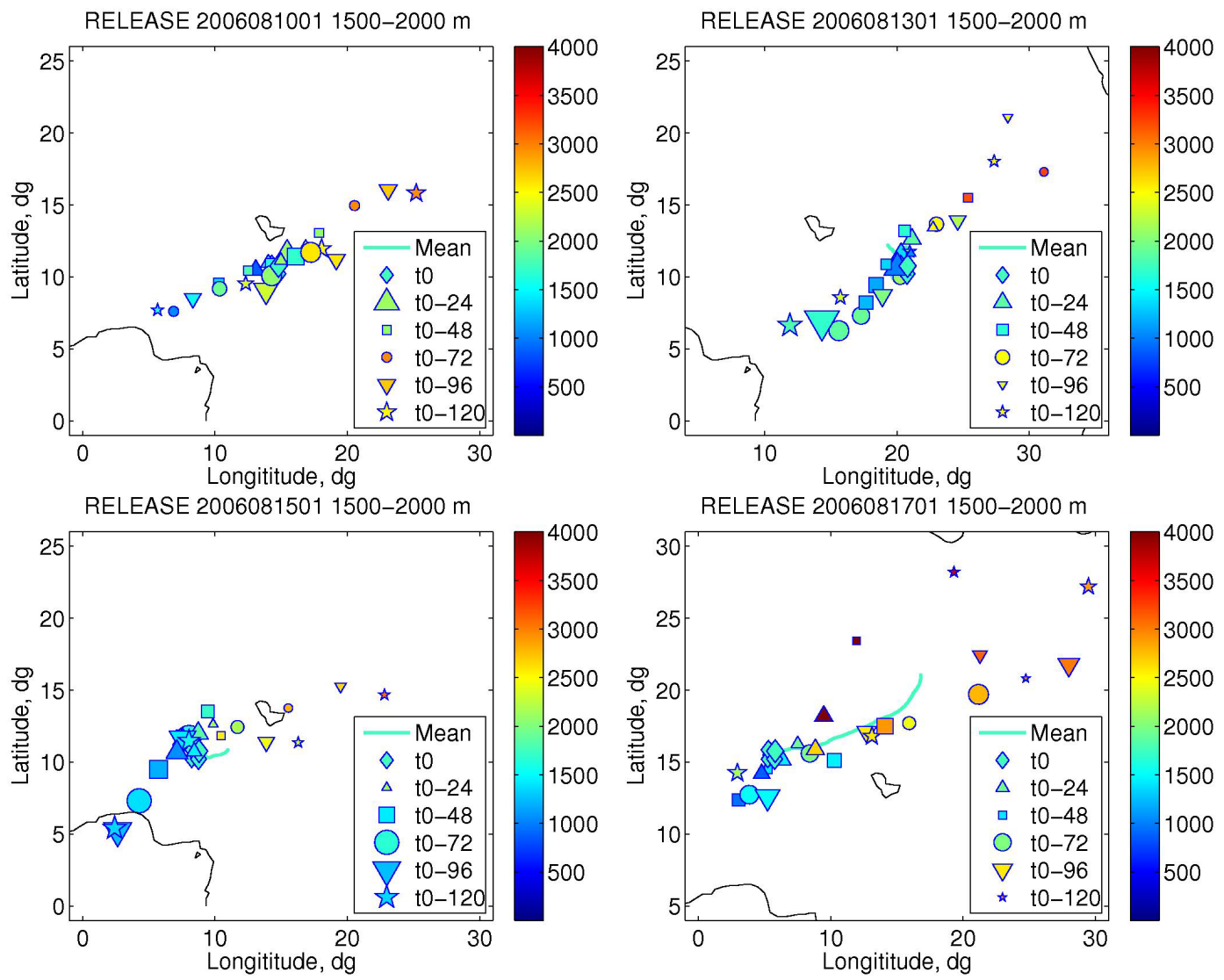

Fig. 15. 5-days FLEXPART backward time position of five clusters of the 2000 particles released at low altitudes (1500-200 m) below a MCS position at 00:00 UT on 10 August (upper left), 13 August (upper right), 15 August (lower left) and 17 August (lower right). The 10 August and 13 August MCS have developed along the trajectories shown in Fig. 14, while the 15 August, 17 August MCS are the studied MCS. The clusters are plotted every $24 \mathrm{~h}$, the color corresponds to their altitude, and the size of each cluster is proportional to the number of particles.

- low level slow advection of the Cotonou plumes near the coast (type III),

- meridional transport of Southern Hemisphere biomass burning emissions related to the southeasterly winds over the equatorial Atlantic ocean (type IV),

Further analysis of the origin of these air masses using the FLEXPART Lagrangian Particle Dispersion Model confirmed the robustness of this classification. The analysis of the four MCSs sampled by the french aircraft pointed out a large variability of chemical composition according to their lifetime and latitudinal position. A sixth type of air mass was identified based on the MCSs chemical outflow properties. This type VI is a mix between fresh vented air from the boundary layer and large scale transport in the upper troposphere. Elevated $\mathrm{CO}$ concentrations in the rear outflow region of the MCS can be related to rapid uplifting of air from the low troposphere during the passage of the MCS. The analysis of air mass transport with the FLEXPART model re- vealed that these elevated concentrations could also have an important contribution from remote convective activity followed by advection by the TEJ in the upper troposphere. These upper tropospheric air masses showed strong connections with the the middle-east region related to the asian summer low pressure system or the biomass burning which occurs in the Southern Hemisphere in this season. The transport pathways are sketched in Fig. 16 and the air masses of type I, III and IV are found near the coast while type II and V air masses are mainly north of the $10^{\circ} \mathrm{N}$ latitude.

Regarding the ozone production in air masses away from the direct outflow of MCS, it is related to (i) the transport of biomass burning emission from the $\mathrm{SH}$, (ii) the city plume near Cotonou and (iii) the aftermath of convective transport over the continent (high $\mathrm{NO}_{\mathrm{x}}$ and high $\mathrm{H}_{2} \mathrm{O}_{2}$ concentrations). The photochemical reactivity of the air masses for these flights are already noticeable in $\mathrm{O}_{3}$ and $\mathrm{CO}$ correlation plots and in the correlation of $\mathrm{H}_{2} \mathrm{O}_{2}$ with a $\mathrm{OH}$ concentration proxy $\left(\left[\mathrm{O}_{3}\right]^{*}\left[\mathrm{H}_{2} \mathrm{O}\right] /[\mathrm{CO}]\right)$, but for the WAM it remains 


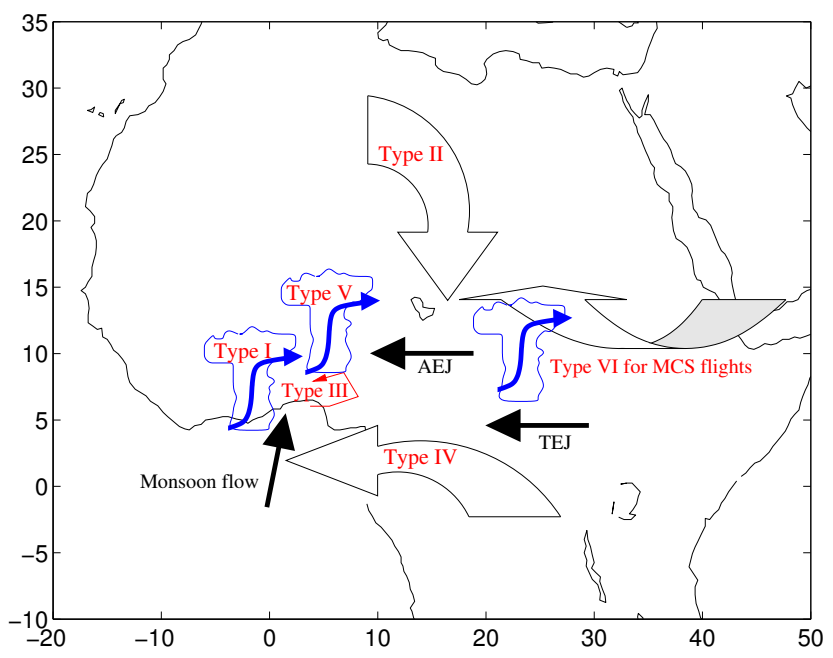

Fig. 16. Schematic view of the main transport pathways (large arrows for the synoptic scale transport, blue arrows for the convective uplifting and the small red arrow for the slow advection of urban pollution at low altitudes) which have been identified as controlling the chemical composition of the mid and upper troposphere above West Africa. The related air mass types defined in this work by the chemical composition measured by the aircraft are also indicated.

difficult to separate photochemistry and dynamical processes on these correlation plots. Regarding the chemical composition of the outflow of the different MCSs, it was shown here that the increase of $\mathrm{CO}$ and $\mathrm{H}_{2} \mathrm{O}_{2}$ and the associated chemical reactivity necessary for subsequent $\mathrm{O}_{3}$ formation, are directly related to the position and the lifetime of the MCS during its evolution. Increased lifetime ( $>1.5$ days) allows more $\mathrm{H}_{2} \mathrm{O}_{2}$ formation, while a trajectory of the MCS crossing the $10^{\circ} \mathrm{N}$ latitude increases the $\mathrm{CO}$ transport to the upper troposphere.

Acknowledgements. Based on a French initiative, AMMA was built by an international scientific group and is currently funded by a large number of agencies, especially from France, the UK, the US and Africa. The UMS SAFIRE is acknowledged for supporting the F-F20 aircraft deployment and for providing the aircraft meteorological data (humidity and dropsondes). This work was supported by the AMMA EC project and INSU. Franck Roux (Laboratoire d'Aérologie) is acknowledged for work on flight planning and validation of the dropsonde data and Ariane Bazureau (Service Aéronomie) is acknowledged for work on FLEXPART modelling.

Edited by: C. Reeves

\section{References}

Aghedo, A. M., Schultz, M. G., and Rast, S.: The influence of African air pollution on regional and global tropospheric ozone,
Atmos. Chem. Phys., 7, 1193-1212, 2007, http://www.atmos-chem-phys.net/7/1193/2007/.

Andreae, M., Fishman, J., and Lindesay, J.: The Southern Tropical Atlantic Region Experiment(STARE): Transport and Atmospheric Chemistry near the Equator- Atlantic(TRACEA) and Southern African Fire-Atmosphere Research Initiative(SAFARI): An Introduction, J. Geophys. Res., 101, 2351923520, 1996.

Andreae, M. O., Anderson, B. E., Blake, D. R., Bradshaw, J. D., Collins, J. E., Gregory, G. L., Sachse, G. W., and Shipham, M. C.: Influence of plumes from biomass burning on atmospheric chemistry over the equatorial and tropical South Atlantic during CITE3, J. Geophys. Res., 99, 12793-12808, 1994.

Barret, B., Ricaud, P., Mari, C., Attié, J.-L., Bousserez, N., Josse, B., Le Flochmoën, E., Livesey, N. J., Massart, S., Peuch, V.H., Piacentini, A., Sauvage, B., Thouret, V., and Cammas, J.P.: Transport pathways of $\mathrm{CO}$ in the African upper troposphere during the monsoon season: a study based upon the assimilation of spaceborne observations, Atmos. Chem. Phys., 8, 3231-3246, 2008 , http://www.atmos-chem-phys.net/8/3231/2008/.

Brioude, J., Cooper, O. R., Trainer, M., Ryerson, T. B., Holloway, J. S., Baynard, T., Peischl, J., Warneke, C., Neuman, J. A., De Gouw, J., Stohl, A., Eckhardt, S., Frost, G. J., McKeen, S. A., Hsie, E.-Y., Fehsenfeld, F. C., and Nédélec, P.: Mixing between a stratospheric intrusion and a biomass burning plume, Atmos. Chem. Phys., 7, 4229-4235, 2007, http://www.atmos-chem-phys.net/7/4229/2007/.

Cho, J., Newell, R., Browell, E., Grant, W., Butler, C., and Fenn, M.: Observation of pollution plume capping by a tropopause fold, Geophys. Res. Lett., 28, 3243-3246, 2001.

Chong, M., Amayenc, P., Scialom, G., and Testud, J.: A tropical squall line observed during the COPT 81 experiment in West Africa. Part I: Kinematic structure inferred from dual-doppler radar data, Mon. Weather Rev., 115, 670-694, 1987.

Christian., H., Blakeslee, R., Boccippio, D., Boeck, W., Buechler, D., Driscoll, K., Goodman, S., Hall, J., Koshak, W., Mach, D., and Stewart, M.: Global frequency and distribution of lightning as observed from space by the Optical Transient Detector, J. Geophys. Res., 108, 4005, doi:10.1029/2002JD002347, 2003.

Cowden, J., Watkins, D., and Mihelcic, J.: Stochastic rainfall modeling in West Africa: Parsimonious approaches for domestic rainwater harvesting assessment, J. Hydrology, 361, 64-77, 2008.

DeCaria, A., Pickering, K., Stenchikov, G., et al.: A cloud-scale model study of lightning-generated $\mathrm{NO}_{\mathrm{x}}$ in an individual thunderstorm during STERAO-A, J. Geophys. Res., 105, 1160111616, 2000.

Delon, C., Reeves, C. E., Stewart, D. J., Serça, D., Dupont, R., Mari, C., Chaboureau, J.-P., and Tulet, P.: Biogenic nitrogen oxide emissions from soils - impact on $\mathrm{NO}_{\mathrm{x}}$ and ozone over West Africa during AMMA (African Monsoon Multidisciplinary Experiment): modelling study, Atmos. Chem. Phys., 8, 2351-2363, 2008 , http://www.atmos-chem-phys.net/8/2351/2008/.

Diongue, A., Lafore, J.-P., and Redelsperger, J.-L.: Numerical study of a synoptic weather system: Initiation and mature stages of convection and its interactions with the large-scale dynamics, Q. J. Roy. Meteorol. Soc., 128, 1899-1927, 2002. 
Drobinski, P., Saïd, F., Ancellet, G., Arteta, J., Augustin, P., Bastin, S., Brut, A., Caccia, J., Campistron, B., Cautenet, S., Colette, A., Coll, I., Corsmeier, U., Cros, B., Dabas, A., Delbarre, H., Dufour, A., Durand, P., Guénard, V., Hasel, M., Kalthoff, N., Kottmeier, C., Lasry, F., Lemonsu, A., Lohou, F., Masson, V., Menut, L., Moppert, C., Peuch, V., Puygrenier, V., Reitebuch, O., and Vautard, R.: Regional transport and dilution during highpollution episodes in southern France: Summary of findings from the Field Experiment to Constraint Models of Atmospheric Pollution and Emissions Transport (ESCOMPTE), J. Geophys. Res., 112, D13105, doi:10.1029/2006JD007494, 2007.

Edwards, D., Lamarque, J., Attie, J., Emmons, L., Richter, A., Cammas, J., Gille, J., Francis, G., Deeter, M., Warner, J., Ziskin, D., Lyjak, L., Drummond, J., and Burrows, J.: Tropospheric ozone over the tropical Atlantic: A satellite perspective, J. Geophys. Res., 108, 4237, doi:10.1029/2002JD002927, 2003.

Fishman, J., Hoell, J., Bendura, R., McNeal, R., and Kirchoff, V.: NASA GTE TRACE-A Experiment (september-october 1992): Overview, J. Geophys. Res., 101, 23665-23879, 1996.

Fontan, J., Druilhet, A., Benech, B., Lyra, R., and Cros, B.: The DECAFE experiments : overview and meteorology, J. Geophys. Res., 97, 6123-6136, 1992.

Giannini, A., Saravanan, R., and Chang, P.: Oceanic forcing of Sahel rainfall on interannual to interdecadal time scales, Science, 302, 1027-1030, 2003.

Grodsky, S. and Carton, J.: Coupled land/atmosphere interactions in the West African Monsoon, Geophys. Res. Lett., 28, 1503-1506, 2001.

Guenther, A., Hewitt, C., Erickson, D., Fall, R., Geron, C., Graedel, T., Harley, P., Klinger, L., Lerdau, M., McKay, W., Pierce, T., Scholes, B., Steinbrecher, R., Tallamraju, R., Taylor, J., and Zimmerman, P.: A global model of natural volatile organic compound emissions, J. Geophys. Res., 100, 8873-8892, 1995.

Heike, B. G., Lee, M., Bradshaw, J., Sandholm, S., Davis, D. D., Crawford, J., Rodriguez, J., Liu, S., McKeen, S., Thornton, D., Bandy, A., Gregory, G., Talbot, R., and Blake, D.: Hydrogen peroxide and methylhydroperoxide distributions related to ozone and odd hydrogen over the North Pacific in the fall of 1991, J. Geophys. Res., 101, 1891-1905, 1996.

Huntrieser, H., Schumann, U., Schlager, H., Höller, H., Giez, A., Betz, H.-D., Brunner, D., Forster, C., Pinto Jr., O., and Calheiros, R.: Lightning activity in Brazilian thunderstorms during TROCCINOX: implications for NOx production, Atmos. Chem. Phys., 8, 921-953, 2008,

http://www.atmos-chem-phys.net/8/921/2008/.

Jaegle, L., Martin, R., Chance, K., Steinberger, L., Kurosu, T., Jacob, D., Modi, A., Yoboue, V., Sigha-Nkamdjou, L., and Galy-Lacaux, C.: Satellite mapping of rain-induced nitric oxide emissions from soils, J. Geophys. Res., 109, 21310, doi:10.1029/2004JD004787, 2004.

Jaegle, L., Steinberger, L., Martin, R., and Chance, K.: Global partitioning of NOx sources using satellite observations: Relative roles of fossil fuel combustion and biomass burning and soil emissions, Faraday Discuss., 130, 407-423, 2005.

J.L.Redelsperger, Thorncroft, C., Diedhiou, A., Lebel, T., Parker, D., and Polcher, J.: African Monsoon Multidisciplinary Analysis: An International Research Project and Field Campaign, B. Am. Meteorol. Soc., 87, 1739-1746, 2006.

Jonquieres, I. and Marenco, A.: Redistribution by deep convec- tion and long-range transport of $\mathrm{CO}$ and $\mathrm{CH} 4$ emissions from the Amazon basin and as observed by the airborne campaign TROPOZ II during the wet season, J. Geophys. Res., 103, 19075-19091, 1998.

Jonquieres, I., Marenco, A., Maalej, A., and Rohrer, F.: Study of ozone formation and transatlantic transport from biomass burning emissions over West Africa during the airborne TROPospheric OZone campaigns TROPOZ I and TROPOZ II, J. Geophys. Res., 103, 19059-19073, 1998.

Kowol-Santen, J. and Ancellet, G.: Mesoscale analysis of transport across the subtropical tropopause, Geophys. Res. Lett., 27, 3345-3348, 2000.

Labrador, L. J., von Kuhlmann, R., and Lawrence, M. G.: The effects of lightning-produced $\mathrm{NO}_{\mathrm{x}}$ and its vertical distribution on atmospheric chemistry: sensitivity simulations with MATCHMPIC, Atmos. Chem. Phys., 5, 1815-1834, 2005, http://www.atmos-chem-phys.net/5/1815/2005/.

Laing, A., Carbone, R., Levizzani, V., and Tuttle, J.: The propagation and diurnal cycles of deep convection in northen tropical Africa, Q. J. Roy. Meteorol. Soc., 134, 93-109, 2008.

Lazrus, A., Kok, L., Lind, J., Gitlin, S., Heikes, B., and Shetter, R.: Automated fluorometric method for hydrogen peroxide in air, Anal. Chem., 58, 594-597, 1988.

Lee, M., Heikes, B., Jacob, D., Sachse, G., and Anderson, B.: Hydrogen peroxide, organic hydroperoxide, and formaldehyde as primary pollutants from biomass burning, J. Geophys. Res., 102(D1), 1301-1309, 1997.

Lee, M., Heikes, B. G., and O'Sullivan, D. W.: Hydrogen peroxide and organic hydroperoxide in the troposphere: a review, Atmos. Environ., 34, 3475-3494, 2000.

Li, Q., Jacob, D. J., Logan, J. A., Bey, I., Yantosca, R. M., Liu, H., Martin, R. V., Fiore, A. M., Field, B. D., Duncan, B. N., and Thouret, V.: A tropospheric ozone maximum over the middle east, Geophys. Res. Lett., 28, 3235-3238, 2001.

Mari, C. and Prospero, J.: African Monsoon Multidisciplinary Analysis-Atmospheric Chemistry (AMMA-AC): a new IGAC task, IGAC Newsletter, 31, 2-13, 2005.

Mari, C. H., Cailley, G., Corre, L., Saunois, M., Attié, J. L., Thouret, V., and Stohl, A.: Tracing biomass burning plumes from the Southern Hemisphere during the AMMA 2006 wet season experiment, Atmos. Chem. Phys., 8, 3951-3961, 2008, http://www.atmos-chem-phys.net/8/3951/2008/.

Marion, T., Perros, P., Losno, R., and Steiner, R.: Ozone Production Efficiency in Savanna and Forested Areas during the EXPRESSO Experiment, J. Atmos. Chem., 38, 3-30, doi:10.1023/A:1026585603100, 2001.

Martin, R., Jacob, D., Logan, J., Ziemke, J., and Washington, R.: Detection of a lightning influence on tropical tropospheric ozone, Geophys. Res. Lett., 27, 1639-1642, 2000.

Martin, R., Jacob, D., Logan, J., Bey, I., Yantosca, R., Staudt, A., Li, Q., Fiore, A., Duncan, B., Liu, H., Ginoux, P., and Thouret, V.: Interpretation of TOMS observations of tropical tropospheric ozone with a global model and in situ observations, J. Geophys. Res., 107, 4351, doi:10.1029/2001JD001480, 2002.

Mohr, K. and Thorncroft, C.: Intense convective systems in West Africa and their relationship to the African easterly jet, Q. J. Roy. Meteorol. Soc., 132, 163-176, 2006.

Nedelec, P., Cammas, J.-P., Thouret, V., Athier, G., Cousin, J.-M., Legrand, C., Abonnel, C., Lecoeur, F., Cayez, G., and Marizy, 
C.: An improved infrared carbon monoxide analyser for routine measurements aboard commercial Airbus aircraft: technical validation and first scientific results of the MOZAIC III programme, Atmos. Chem. Phys., 3, 1551-1564, 2003,

http://www.atmos-chem-phys.net/3/1551/2003/.

Olivier, J., Bouwman, A., Berdowski, J., Bloos, J., Visschedijk, A., van der Mass, C., and Zandveld, P.: Sectoral emission inventories of greenhouse gases for 1990 on a per country basis as well as on $1 \times 1$ degrees, Environ. Sci. Policy, 2, 241-263, 1999.

Parker, D., Thorncroft, C., Burton, R., and Diongue-Niang, A.: Analysis of the African easterly jet and using aircraft observations from the JET2000 experiment, Q. J. Roy. Meteorol. Soc., 131, 1461-1482, 2005.

Parrish, D. D., Holloway, J. S., Trainer, M., Murphy, P. C., Forbes, G. L., and Fehsenfeld, F. C.: Relationship between ozone and carbon monoxide at surface sites in the North Atlantic region, J. Geophys. Res., 103, 13357-13376, 1998.

Peyrille, P., Lafore, J., and Redelsperger, J.: An idealized twodimensional framework to study the West African monsoon. Part I: Validation and key controlling factors, J. Atmos. Sci., 64, 2765-2782, 2007.

Pickering, K., Thompson, A., Scala, J., Tao, W., Simpson, J., and Garstang, M.: Photochemical ozone production in tropical squall line convection during NASA global tropospheric experiment/amazon boundary layer experiment 2 A, J. Geophys. Res., 96, 3099-3114, 1991.

Pickering, K., Thompson, A. M., Tao, W., and Kucsera, T. L.: Upper tropospheric ozone production following mesoscale convection during STEP/EMEX, J. Geophys. Res., 98, 8737-8749, 1993.

Pickering, K., Thompson, A. M., Wang, Y., Tao, W., McNamara, D., Kirchhoff, V., Heikes, B., Sachse, G., Bradshaw, J., Gregory, G., and Blake, D. R.: Convective Transport of Biomass Burning Emissions over Brazil during TRACE-A, J. Geophys. Res., 101, 23993-24012, 1996.

Prather, M. and Jacob, D.: A Persistent Imbalance in $\mathrm{HO}_{\mathrm{x}}$ and $\mathrm{NO}_{\mathrm{x}}$ Photochemistry of the Upper Troposphere Driven by Deep Tropical Convection, Geophys. Res. Lett., 24, 3189-3192, 1997.

Redelsperger, J., Diongue, A., Diedhou, A., Ceron, J., Diop, M., Gueremy, J., and Lafore, J.: Multi-scale description of a Sahelian synoptic weather system representative of the West African Monsoon, J. Geophys. Res., 128, 1229-1257, 2002.

Reeves, C. E. and Penkett, S. A.: Measurements of Peroxides and What They Tell Us, Chem. Rev., 103, 5199-5218, 2003.

Reeves, C., Ancellet, G., Borbon, A., Cairo, F., Law, K., Mari, C., Methven, J., Schlager, H., and Thouret, V.: Chemical characterization of the troposphere over West Africa during the monsoon period as part of AMMA, Atmos. Chem. Phys. Discuss., in preparation, 2009.

Roca, R., Lafore, J.-P., Piriou, C., and Redelsperger, J.-L.: Extratropical dry air intrusions into the West African Monsoon midtroposphere: an important factor for the convective activity over Sahel, J. Atmos. Sci., 62, 390-407, 2005.

Saunois, M., Mari, C., Thouret, V., Cammas, J., Peyrille, P., Lafore, J., Sauvage, B., Volz-Thomas, A., Nedelec, P., and Pinty, J.: An idealized two-dimensional approach to study the impact of the West African monsoon on the meridional gradient of tropospheric ozone, J. Geophys. Res., 113, 7306, doi:10.1029/2007JD008707, 2008.
Sauvage, B., Thouret, V., Cammas, J.-P., Gheusi, F., Athier, G., and Nédélec, P.: Tropospheric ozone over Equatorial Africa: regional aspects from the MOZAIC data, Atmos. Chem. Phys., 5, 311335,2005 ,

http://www.atmos-chem-phys.net/5/311/2005/.

Sauvage, B., Thouret, V., and Thompson, A.: Enhanced view of the "tropical Atlantic ozone paradox" and "zonal wave one" from the in situ MOZAIC and SHADOZ data, J. Geophys. Res., 111, 1301, doi:10.1029/2005JD006241, 2006.

Sauvage, B., Gheusi, F., Thouret, V., Cammas, J.-P., Duron, J., Escobar, J., Mari, C., Mascart, P., and Pont, V.: Medium-range midtropospheric transport of ozone and precursors over Africa: two numerical case studies in dry and wet seasons, Atmos. Chem. Phys., 7, 5357-5370, 2007a, http://www.atmos-chem-phys.net/7/5357/2007/.

Sauvage, B., Martin, R. V., van Donkelaar, A., and Ziemke, J. R.: Quantification of the factors controlling tropical tropospheric ozone and the South Atlantic maximum, J. Geophys. Res., 112, 11309, doi:10.1029/2006JD008008, 2007b.

Sauvage, B., Thouret, V., Cammas, J.-P., Brioude, J., Nédélec, P., and Mari, C.: Meridional ozone gradients in the African upper troposphere, Geophys. Res. Lett., 34, 3187, doi:10.1029/2006GL028542, 2007c.

Scala, J. R., Garstang, M., Tao, W. K., Pickering, K. E., Thompson, A. M., Simpson, J., Kirchhoff, V. M., Browell, E. V., Sachse, G. W., Torres, A. L., Gregory, G. L., Rasmussen, R. A., and Khalilet, M. K.: Cloud draft structure and trace gas transport, J. Geophys. Res., 95, 17015-17030, 1990.

Schumann, U. and Huntrieser, H.: The global lightning-induced nitrogen oxides source, Atmos. Chem. Phys., 7, 3823-3907, 2007, http://www.atmos-chem-phys.net/7/3823/2007/.

Serca, D., R, R. D., Roux, X. L., Parsons, D., Scholes, M., Abbadie, L., Lensi, R., Ronce, O., and Labroue, L.: Comparison of nitrogen monoxide emissions from several African tropical ecosystems and influence of season and fire, Global Biogeochem. Cycles, 12, 637-651, 1998.

Snow, J., Heikes, B., O'Sullivan, D., Shen, E., Fried, A., and Walega, J.: Hydrogen peroxide and methylhydroperoxide mixing ratios over North America and the North Atlantic during INTEX-NA., J. Geophys. Res., 112, D12S07, doi:10.1029/2006JD007746, 2007.

Stewart, D. J., Taylor, C. M., Reeves, C. E., and McQuaid, J. B.: Biogenic nitrogen oxide emissions from soils: impact on $\mathrm{NO}_{\mathrm{x}}$ and ozone over west Africa during AMMA (African Monsoon Multidisciplinary Analysis): observational study, Atmos. Chem. Phys., 8, 2285-2297, 2008, http://www.atmos-chem-phys.net/8/2285/2008/.

Stohl, A., Hittenberger, M., and Wotawa, G.: Validation of the Lagrangian particle dispersion model FLEXPART against large scale tracer experiment data, Atmos. Environ., 32, 4245-4264, 1998.

Stohl, A., Eckhardt, S., Forster, C., James, P., Spichtinger, N., and Seibert, P.: A replacement for simple back trajectory calculations in the interpretation of atmospheric trace substance measurements, Atmos. Environ., 36, 4635-4648, 2002.

Thompson, A., Pickering, K. E., Dickerson, R. R., Ellis, W. G., Jr., Jacob, D. J., Scala, J. R., Tao, W.-K., McNamara, D. P., and Simpson, J.: Convective transport over the central United States and its role in the regional $\mathrm{CO}$ and ozone budgets, J. Geophys. 
Res., 99, 18703-18711, 1994.

Thompson, A., Pickering, K., McNamara, D., Schoeberl, M., Hudson, R., Kim, J., Browell, E., Kirchhoff, V., and Nganga, D.: Where did tropospheric ozone over southern Africa and the tropical Atlantic come from in October 1992? Insights from TOMS and GTE TRACE A and and SAFARI 1992, J. Geophys. Res., 101, 24251-24278, 1996.

Thompson, A., Doddridge, B., Witte, J., Hudson, R., Luke, W., Johnson, J., Johnson, B., Oltmans, S., and Weller, R.: A tropical Atlantic paradox: Shipboard and satellite views of a tropospheric ozone maximum and wave-one in January-February 1999, Geophys. Res. Lett., 27(20), 3317-3320, 2000.
Thorncroft, C. and Blackburn, M.: Maintenance of the African easterly jet, Q. J. Roy. Meteorol. Soc., 125, 763-786, 1999.

Zeng, N., Neelin, D., Lau, J., and Tucker, C.: Enhancement of interdecadal climate variability in the Sahel by vegetation interaction, Science, 286, 1537-1540, 1999.

Zhang, J., Rao, S., and Daggupaty, S.: Meteorological processes and ozone exceedances in the Northeastern United States during the 12-16 July 1995 episode, J. Appl. Meteor., 37, 776-789, 1998.

Zipser, E., Cecil, D., Liu, C., Nesbitt, S., and Yorty, D.: Where are the most intense thunderstorms on earth?, B. Am. Meteorol. Soc., 87, 1057, doi:10.1175/BAMS-87-8-1057, 2006. 